\title{
Evolution of the Southwest Australian Rifted Continental Margin During Breakup of East Gondwana: Results from IODP Expedition 369
}

\author{
D. L. Harry ${ }^{1}$, M. L. G. Tejada ${ }^{2}$, E. Y. Lee ${ }^{3}$, E. Wolfgring 4 , C. C. Wainman ${ }^{5}$, H.-J.
} Brumsack $^{6}$, B. Schnetger ${ }^{6}$, J.-I. Kimura ${ }^{2}$, L. Riquier ${ }^{7}$, I. Borissova ${ }^{8}$, R. Hobbs ${ }^{9}$, T. Jiang ${ }^{10}$, Y-X. Li ${ }^{11}$, A. Maritati' ${ }^{12}$, M. Martinez ${ }^{13}$, C. Richter ${ }^{14}$, G. Tagliaro ${ }^{15}$, and L. T. White ${ }^{16}$

${ }^{1}$ Department of Geosciences, Colorado State University, Fort Collins, CO, 80537, USA.

${ }^{2}$ Institute for Marine Geodynamics, Japan Agency for Marine-Earth Science and Technology, 215 Natsushima-cho, Yokosuka-shi, Kanagawa 237-0061, Japan.

${ }^{3}$ Faculty of Earth Systems and Environmental Sciences, Chonnam National University, 33 Yongbong-no, Bukgu, Gwangju 61186, Republic of Korea.

${ }^{4}$ Department of Geodynamics and Sedimentology, University of Vienna, Vienna 1090, Austria.

${ }^{5}$ Australian School of Petroleum and Energy Resources, University of Adelaide, Adelaide 5005, Australia.

${ }^{6}$ Institut für Chemie und Biologie Des Meeres (ICBM), Carl von Ossietzky Universität Oldenburg, Oldenburg Lower Saxony 26111, Germany.

${ }^{7}$ Institut des sciences de la Terre de Paris (ISTeP), Sorbonne University, Paris 75005, France.

${ }^{8}$ Geoscience Australia, Petroleum and Marine Division, GPO Box 378, Canberra ACT 2601, Australia.

${ }^{9}$ Department of Earth Sciences, University of Durham, Durham DH1 3LE, United Kingdom.

${ }^{10}$ Department of Marine Science and Engineering, China University of Geosciences, Hongshan Street, Wuhan, P.R. China.

${ }^{11}$ School of Earth Sciences and Engineering, Nanjing University, Nanjing 210046, P.R. China.

${ }^{12}$ Institute of Marine and Antarctic Studies (IMAS), University of Tasmania, Battery Point 7004, Australia.

${ }^{13}$ Univ Rennes, CNRS, Géosciences Rennes, UMR 6118, 35000 Rennes, France.

School of Geosciences, University of Louisiana at Lafayette, Lafayette LA 70504, USA.

${ }^{15}$ Department Institute for Geophysics, University of Texas at Austin, Austin TX 78758, USA.

${ }^{16}$ GeoQuEST Research Centre, School of Earth, Atmospheric and LifeSciences, University of Wollongong, Wollongong NSW 2522, Australia.

Corresponding author: Dennis Harry (Dennis.Harry@ colostate.edu)

\section{Key Points:}

- Continental breakup occurred at 132-133 Ma on the Perth Abyssal Plain and at $126 \mathrm{Ma}$ west of the Naturaliste Plateau.

- Volcanism on the Naturaliste Plateau with both plume and midocean ridge compositional affinities accompanied Perth Abyssal Plain breakup.

This article has been accepted for publication and undergone full peer review but has not been through the copyediting, typesetting, pagination and proofreading process, which may lead to differences between this version and the Version of Record. Please cite this article as doi: 10.1029/2020GC009144. 
- Late syn- and early post-rift subsidence was limited by proximity of the Kerguelen plume and Perth Abyssal Plain spreading ridge.

This article is protected by copyright. All rights reserved. 


\begin{abstract}
International Ocean Discovery Program Expedition 369 drilled four sites on the southwestern Australian continental margin, in the deep water Mentelle Basin (MB) and on the neighboring Naturaliste Plateau (NP). The drillsites are located on continental crust that continued rifting after seafloor spreading began further north on the Perth Abyssal Plain (PAP) between magnetochrons M11r and M11n (133-132 Ma), ending when spreading began west of the NP between chrons M5n and M3n (126-124 Ma). Drilling recovered the first in-situ samples of basalt flows overlying the breakup unconformity on the NP, establishing a magnetostratigraphically constrained eruption age of $>131-133$ Ma and confirming a minimal late Valanginian age for the breakup unconformity (coeval with the onset of PAP seafloor spreading). Petrogenetic modeling indicates the basalts were generated by $25 \%$ melting at 1.5 GPa and a potential temperature of $1380-1410{ }^{\circ} \mathrm{C}$, consistent with proximity of the Kerguelen plume during breakup. Benthic foraminiferal fossils indicate that the NP remained at upper bathyal or shallower depths during the last 6 Myr of rifting and for 3-5 Myr after breakup between India and Australia. The limited subsidence is attributed to heat from the nearby Kerguelen plume and PAP spreading ridge. The margin subsided to middle bathyal depths by Albian time and to lower bathyal (NP) or greater (MB) depths by late Paleogene time. Periods of rapid sedimentation accompanied a westward jump of the PAP spreading ridge (108 Ma), rifting on the southern margin (100-84 Ma), and opening of the southern seaway between Australia and Antarctica (60-47 Ma).
\end{abstract}

\title{
Plain Language Summary
}

The southwestern Australian margin formed during the breakup of the supercontinent Gondwana during the Late Jurassic and Early Cretaceous Periods. International Ocean Discovery Program Expedition 369 drilled four sites on the southwestern Australian rifted continental margin in order to better understand the subsidence and magmatic behavior of the margin during the final stages of rifting. Drilling shows that a widespread unconformity imaged in seismic data on the margin correlates with the onset of seafloor spreading on the Perth Abyssal Plain at 132-133 Ma. This was followed by eruption of basalts on the Naturaliste Plateau, which were generated from melting of the underlying mantle that was enhanced by the nearby Kerguelen mantle plume. Proximity of the plume kept the margin at shallow depths during rifting and for about 3-5 Myr after final separation of India and Australia at $126 \mathrm{Ma}$. The margin subsided to $>1000 \mathrm{~m}$ depths between about $121 \mathrm{Ma}$ and the present, with intervening periods of relatively rapid sedimentation associated with adjustments to the spreading ridge configuration in the Indian Ocean at $108 \mathrm{Ma}$, and rifting events between southwestern Australia and Antarctica at 100-84 Ma and 60-47 Ma.

\section{Introduction}

In this paper, we present new constraints on the late syn-rift and post-rift evolution of the southwestern Australian continental margin from boreholes drilled during International Ocean Discovery Program (IODP) Expedition 369. The western Australian margin formed as a result of Late Jurassic through Early Cretaceous rifting as Greater India separated from Australia during the breakup of East Gondwana (the discussion here follows Gibbons et al., 2012, with ages modified to fit recent revisions to the geomagnetic time scale as discussed in section 2.1). Rift basins formed beneath the continental shelf along most of the western Australian margin during this time, reactivating Permian rift structures in many areas (Hall et al., 2013; Yeates et al., 1987). On the southwestern part of the margin, extension occurred in the Perth Basin beneath the

This article is protected by copyright. All rights reserved. 
continental shelf and in the deep water Mentelle Basin and on the Naturaliste Plateau further offshore (Figure 1). Breakup was diachronous, with seafloor spreading beginning on the Perth Abyssal Plain no later than chron M10N (131 Ma) and between M11r and M11n (133-132 Ma) on the central part of the margin. Seafloor spreading did not begin until between chrons M5n and M3n (126-124 Ma) on the southwestern part of the margin, west of the Naturaliste Plateau. The culmination of rifting between Greater India and Australia is thus marked by two breakup events. The first, which we refer to as the Perth Abyssal Plain breakup event, occurred when seafloor spreading was established on the Perth Abyssal Plain and produced a widely recognizable breakup unconformity in the Perth Basin. The second, which we refer to as the Naturaliste Plateau breakup event, occurred when seafloor spreading was established west of the Naturaliste Plateau. During the 6-9 Myr period between the two breakup events, the spreading ridge in the Perth Abyssal Plain migrated westward along the northern margins of the Mentelle Basin and Naturaliste Plateau. The Perth Abyssal Plain breakup event was followed soon after by eruption of basalt flows, which lie on top of the breakup unconformity on the Naturaliste Plateau, in the western Mentelle Basin, and in the southern Perth Basin (Direen et al., 2017; Frey et al., 1996; Olierook et al., 2016). The culminating tectonic event on the margin was the Cretaceous through Eocene rifting episode that led to opening of the Southern Ocean between Australia and Antarctica. This rifting event began around $100 \mathrm{Ma}$ on the southern margin of western Australia, leading to slow spreading by about $84 \mathrm{Ma}$ that propagated eastward until separation of the South Tasman Rise from Antarctica at about 45 Ma (Cande and Mutter, 1982; Lawver et al., 1992; Mutter et al., 1985; Sayers et al., 2001; Tikku and Cande, 1999; Tikku and Direen, 2008; Veevers, 1986, 2006; White et al., 2013; Williams et al., 2013). IODP Expedition 369 obtained the first in-situ record of the volcanic sequence on the Naturaliste Plateau and a complete record of the late syn-rift and post-rift strata on the southwestern Australian margin in order to understand the magmatic and subsidence histories of the margin and their relations to the tectonic events described above (Hobbs et al., 2019; Huber et al., 2018).

\section{Geological Background}

\subsection{Plate motions and seafloor spreading}

The timing of continental breakup in the northeastern Indian Ocean and on the southwestern Australian margin is constrained primarily from seafloor spreading magnetic anomalies (e.g., Ali and Aitchison, 2014; Direen et al., 2017; Gaina et al., 2007; Gibbons et al., 2012, 2013; Hall et al., 2013; Watson et al., 2016; White et al., 2013; Whittaker et al., 2016; Williams et al., 2013 and earlier references found in those papers). In this paper we use the magnetic anomaly identifications described in the plate reconstructions of Gibbons et al. (2012) and Williams et al. (2013). The ages assigned to the Cenozoic magnetic chrons are from the time scale of Ogg et al. (2016). The Late Cretaceous chron ages are from Malinverno et al. (2012), with the ages of chrons M0r through M11r revised here to match the Valanginian to Barremian stage ages indicated by recent radio-astrochronological data integrated with bio- and chemostratigraphy (Aguirre-Urreta et al., 2019; Bodin et al., 2006; Frau et al., 2018; Martinez et al., 2013; Olierook, Jourdan, and Merle, 2019) (Tables 1 and 2). From these works, the Hauterivian Stage started at 131.3 $\pm 0.2 \mathrm{Ma}$, the Barremian Stage at 126.1 $\pm 0.2 \mathrm{Ma}$ and the Aptian Stage at $121.5 \pm 0.2 \mathrm{Ma}$. The revised stage and chron ages imply ages for the Early Cretaceous events described below that are 3-5 Myr younger than in the plate reconstructions of Gibbons et al. $(2012,2013)$.

This article is protected by copyright. All rights reserved. 
Opening of the Indian Ocean was preceded by a Permian extensional episode that created a rift system with branches between Australia and Antarctica and on either side of India (Harrowfield et al., 2005; Maritati et al., 2020; Veevers, 2006; Yeates et al., 1987) (Figure 2a). This was followed by a period of tectonic quiescence and regional subsidence extending into Middle Jurassic time, punctuated with minor extensional events during the Triassic and Early Jurassic Periods (Norvick, 2004; Plumb, 1979). Rifting was renewed during the Middle Jurassic Period as East and West Gondwana began to separate (Besse and Courtillot, 1988; Lawver et al., 1992; Norton and Sclater, 1979; Powell et al., 1988; Royer and Sandwell, 1989). This was accompanied by counterclockwise rotation of India away from Australia/Antarctica, resulting in northwest oriented extension on the western Australian margin and minor extension between Australia and Antarctica beginning about $165 \mathrm{Ma}$ (Ball et al., 2013; Direen et al., 2008, 2011; Gibbons et al., 2013; Lawver et al., 1992; Powell et al., 1988) (Figure 2b). At this time, the Naturaliste Plateau was located at the juncture of the Indian Plate and the future boundary between the Australian and Antarctic plates. Two smaller continental blocks, Batavia and Gulden Draak Knolls, lay respectively to the north and southwest of the Naturaliste Plateau (Gibbons et al., 2013; Whittaker et al., 2016; Williams et al., 2013). Seafloor spreading between Greater India and Australia began on the Cuvier Abyssal Plain bordering the northwestern Australian margin, where it was underway by anomaly M11n to M10N time (132-131 Ma) (Fullerton et al., 1989; Gibbons et al., 2012; Heine and Müller, 2005; Markl, 1978; Robb et al., 2005). This was contemporaneous with or followed soon after by seafloor spreading on the Perth Abyssal Plain bordering the central western Australian margin (the Perth Abyssal Plain breakup event), which was also underway by anomaly M11n to M10N time (Gibbons et al., 2012; Markl, 1974, 1978; Powell et al., 1988; Williams et al., 2013) (Figure 2c). Seafloor spreading was not established west of the Naturaliste Plateau (the Naturaliste Plateau breakup event) until anomaly M5n to M3n time (126-124 Ma) (Gibbons et al., 2012; Müller et al., 2000) (Figure 2d).

The difference in ages of breakup west of the Naturaliste Plateau and on the Perth Abyssal Plain indicates that extension continued on the Naturaliste Plateau/Mentelle Basin portion of the southwestern Australian margin for ca. 6-9 Myr after seafloor spreading had begun further north. The spreading ridge on the Perth Abyssal Plain migrated westward along the northern Mentelle Basin and Naturaliste Plateau margins during this period, followed by a westward jump at anomaly M0r time (121.8 Ma) (Gibbons et al., 2012). Gulden Draak and Batavia Knolls remained attached to the Indian plate until about $108 \mathrm{Ma}$, when the ridge again jumped westward and transferred these continental fragments to the Australian plate (Williams et al., 2013; Whittaker et al., 2016) (Figure 2e).

A change in plate motions occurred at about $100 \mathrm{Ma}$ as India began to move northward (Gibbons et al., 2012, 2013; Mathews et al., 2012; Whittaker et al., 2013; 2016) (Figure 2f). This was accompanied by reorientation of the Indian Ocean spreading system and the onset of rifting between Australia and Antarctica. A period of either slow seafloor spreading (Ball et al., 2013; Cande and Mutter, 1982; Müller et al., 2000; Mutter et al., 1985) and/or mantle exhumation (Direen et al., 2011; White et al., 2013) began diachronously between about 84 and $47 \mathrm{Ma}$ as spreading propagated eastward along the southern margin (Figures $2 \mathrm{~g}$ and $2 \mathrm{~h}$ ). Steady state seafloor spreading and generation of new basaltic oceanic crust was underway between Australia and Antarctica by chron C21 to C19 time (47-42 Ma) (Direen et al., 2011; Gibbons et al., 2012; Mutter et al., 1985; White et al., 2013; Williams et al., 2013).

This article is protected by copyright. All rights reserved. 


\subsection{Structure and stratigraphy}

Extensional structures on the western Australian rifted margin lie west of the Darling Fault, a long-lived structure bordering the western edge of the Archean Yilgarn Craton (Veevers, 2006) (Figure 1). The Perth Basin, a rift basin containing up to $15 \mathrm{~km}$ of late Paleozoic, Mesozoic and Cenozoic strata, lies to the west of the Darling Fault and follows the trend of the older Permian rift system beneath the continental shelf and slope (Harris, 1994; Norvick, 2004; Song and Cawood, 2000; Yeates et al., 1987). On the central part of the margin, the west side of the Perth Basin (Houtman and Zeewyck sub-basins) is separated from oceanic crust on the Perth Abyssal Plain by a discontinuous structural high marking the ocean-continent transition zone (Bradshaw et al., 2003). On the southern part of the margin, a structural high underlain by continental crust (the Yallingup Shelf) borders the west side of the Perth Basin, separating it from the deep water Mentelle Basin (Figure 1).

Seismic reflection profiles image a breakup unconformity in the Mentelle Basin that is similar to the widespread breakup unconformity drilled in the Perth Basin and has been inferred to be of similar (Valanginian) age (Figure 3) (Borissova, 2002; Borissova et al., 2010; Bradshaw et al., 2003; Maloney et al., 2011). The eastern Mentelle Basin, located beneath the continental slope in water depths of 500-2000 m, contains up to $1 \mathrm{~km}$ of post-rift sedimentary strata above the unconformity that thins and onlaps onto the western side of the Yallingup Shelf (Figure 3a). Strata below the seismically imaged breakup unconformity in the eastern Mentelle Basin are heavily extensionally faulted, as in the Perth Basin. The western Mentelle Basin lies in water depths of 2000-4000 $\mathrm{m}$ and contains up to $2.7 \mathrm{~km}$ of post-rift strata that onlap and cover the eastern flank of the Naturaliste Plateau (Figures 3b, 3c). The western Mentelle Basin contains fewer faults than the eastern Mentelle Basin, but abundant volcanic features on top of the breakup unconformity that are similar to features imaged on seismic data from the main part of the Naturaliste Plateau further west (Borissova, 2002). Seismic reflection data show several rift basins beneath the unconformity on the Naturaliste Plateau and in the western Mentelle Basin that are filled with divergent dipping reflectors suggestive of either siliciclastic or volcanic/volcaniclastic growth strata (Borissova, 2002; Hall et al., 2013; Maloney et al., 2011), but these strata have not been drilled.

Basement rocks dredged from the southern Naturaliste Plateau include Mesoproterozoic metasedimentary rocks and orthogneiss that have been correlated with similar rocks exposed in the Albany-Fraser-Wilkes orogen onshore on the southern Australian margin and the conjugate Antarctica margin (Halpin et al., 2008, 2020) (Figure 1). Mafic clasts recovered from dredge hauls on the north and south margins of the plateau, volcaniclastic strata drilled above the breakup unconformity at Deep Sea Drilling Project (DSDP) Sites 258 and 264 (located on the northeastern and southern margins of the plateau, respectively) and seismic profiling have shown the basement of the plateau is capped with basaltic rocks that are similar in age and geochemical characteristics to the Bunbury Basalt that outcrops onshore and has been drilled in the southern Perth Basin (Coleman et al., 1982; Direen et al., 2017). Gravity models indicate the thickness of the crust (including the syn- and post-rift sediments) is more than $35 \mathrm{~km}$ beneath the Yilgarn craton, 30-35 km beneath the Yallingup Shelf, 20-25 km in the Perth Basin, 18-20 km on the Naturaliste Plateau, and about $17 \mathrm{~km}$ in the northern Mentelle Basin (Direen et al., 2007; Olierook et al., 2016). Gravity models permit that the crystalline crust in the western Mentelle Basin (excluding post-rift strata) may be less than $5 \mathrm{~km}$ thick (Johnston et al., 2010). Assuming a pre-rift crust thickness similar to that on the Yallingup Shelf or Yilgarn Craton $(30-35 \mathrm{~km})$, the

This article is protected by copyright. All rights reserved. 
corresponding extension factors are $\beta \approx 1.4-1.6$ on the Naturaliste Plateau and in the Perth Basin and $\beta \approx 3$ beneath the central Mentelle Basin (Olierook et al., 2016).

\subsection{Magmatism and the role of the Kerguelen Plume}

Continental breakup in the eastern Indian Ocean was accompanied by mafic volcanism between 137 to $130 \mathrm{Ma}$ in the southern Perth Basin (exposed onshore as the Bunbury Basalt) (Olierook et al., 2016) and between at least 131 to $128 \mathrm{Ma}$ on the Naturaliste Plateau (Direen et al., 2017; Olierook et al., 2017). Seismic reflection data show volcanic edifices and flows atop the breakup unconformity on most of the Naturaliste Plateau and throughout the western Mentelle Basin, and seaward dipping reflectors interpreted to be volcanic flows have been imaged near the ocean-continent boundary in the northern Perth Basin and on the margin of the Wallaby Plateau (Borissova, 2002; Bradshaw et al., 2003; Colwell et al., 1994; Goncharov \& Nelson 2012; Owens et al., 2018; Norvick, 2004; Symonds et al., 1998). Similar age basalts are present on the conjugate Greater Indian margin, now exposed in southern Tibet (the 140-130 Ma Comei basalts; Liu et al., 2015; Zhou et al., 2017; Zhu et al., 2009). Based on spatial proximity and trace element and isotopic similarities, the Bunbury Basalt, Naturaliste Plateau basalts, and Comei basalts have been inferred to be petrogenetically related to younger basalts produced by the Kerguelen mantle plume on the Wallaby Plateau (124 Ma) (Olierook et al., 2015), eastern Indian margin (the 118 Ma Rajmahal Traps and Cona Basalts) (Baksi, 1995; Baksi et al., 1987; Ingle et al., 2004; Kent et al., 2002; Zhu et al., 2008), and Kerguelen Plateau (>119-100 Ma) (Coffin et al., 2002; Duncan, 2002; Frey et al., 2000; Ingle et al., 2002; Mahoney et al., 1995; Whitechurch et al., 1992). The presence of a ca. $1000 \mathrm{~km}$ diameter Kerguelen plume head beneath the lithosphere at the time of breakup has been proposed to account for the broad paleogeographic distribution of these basalts (Figure 2c) (Direen et al., 2017; Frey et al., 1996; Ingle et al., 2004; Ingle et al., 2002; Kent et al., 2002; Olierook et al., 2016; Olierook et al., 2017; Storey et al., 1989; Zhou et al., 2017; Zhu et al., 2009). However, other models for petrogenesis of the basalts emplaced around the Indian Ocean during rifting and breakup have also been proposed. Regional contamination of the asthenospheric mantle by the broad Kerguelen plume head has been suggested to have increased the fertility and enriched the isotopic and trace element compositions of the mantle prior to rifting, perhaps creating an antecedent plume-like reservoir that was tapped at various times and places during rifting (Kent, 1991; Storey et al., 1989). Alternatively, the Kerguelen plume may have fragmented or segregated into spatially distinct rising limbs, thus accounting for the broad and irregular distribution of the volcanic rocks (Coffin et al., 2002). Lastly, isotopic data suggesting a mixture of both depleted and enriched sources have been interpreted to indicate derivation from sources in the depleted asthenospheric mantle combined with either sub-lithospheric mantle (Olierook et al., 2016) or lithospheric mantle (Olierook, Jiang, et al., 2019) that was enriched in incompatible elements during the Late Proterozoic assembly of East Gondwana. Thus, the relationship between plumes and Early Cretaceous basalts in the eastern Indian Ocean remains uncertain. Opening of the Southern Ocean between Australia and Antarctica in Late Cretaceous through Paleogene time appears to have been amagmatic prior to the onset of seafloor spreading (Direen et al., 2011).

\section{Findings from IODP Expedition 369}

IODP Expedition 369 drilled one site at the western edge of the Mentelle Basin above the eastern flank of the Naturaliste Plateau (Site U1513), two sites in the central Mentelle Basin

This article is protected by copyright. All rights reserved. 
(Sites U1514 and U1516), and one site in the eastern Mentelle Basin near the Yallingup Shelf (Site U1515) (Hobbs et al, 2019; Huber et al., 2018) (Figure 1). Key outcomes of the expedition were recovery of i) strata spanning the breakup unconformity in the eastern Mentelle Basin; ii) the first samples of in-situ basalts on the Naturaliste Plateau, which provide new constraints on the thermal state of the mantle during rifting; iii) a complete clastic succession containing weathered volcanic material deposited on the Naturaliste Plateau between the Perth Abyssal Plain and Naturaliste Plateau breakup events; and iv) nearly complete post-breakup successions on the Naturaliste Plateau and in the Mentelle Basin, which provide new constraints on the subsidence history of the southwestern Australian margin.

IODP Hole U1515A was drilled to a depth of 517 meters below seafloor (mbsf) in $850 \mathrm{~m}$ of water on the eastern margin of the Mentelle Basin, on the continental rise adjacent to the Yallingup Shelf (Figures 1 and 3a). Two lithostratigraphic units were identified (Figure 4). Unit I consists of a Pleistocene to upper Campanian or upper Santonian dominantly ooze, chalk, chert, and limestone sequence encountered in the upper $129 \mathrm{~m}$ of the hole. Benthic foraminifera indicate deposition in bathyal water depths (200-2000 m) for most of unit I, with outer neritic (up to $200 \mathrm{~m}$ ) to upper bathyal $(200-600 \mathrm{~m})$ depths in the uppermost part of the unit. An interval of poor recovery across a detachment surface separates unit I from glauconitic sandstone, sand, and silty sand in lithostratigraphic unit IIa between 210-325 mbsf. A 10 m interval of poor recovery separates unit IIa from unit IIb. At its top, unit IIb is dominantly sandstone with interbedded siltstone and claystone that is distinguished from unit IIa by the presence of pyrite and less abundant glauconite. Unit IIb transitions downward across a poorly recovered boundary between 376-402 mbsf into lithostratigraphic unit IIc, which is an organic-rich silty sandstone and claystone containing coal, plant debris, fern pollen, freshwater algae, and possible indicators of dinoturbation. Palynomorphs indicate an earliest Cretaceous (Valanginian or younger) age for lithostratigraphic unit IIb and a Late Jurassic (Kimmeridgian to Tithonian) age for unit IIc (Wainman et al., 2020). Unit IIc is interpreted to have been deposited in a fluvio-lacustrine environment in the upper part of the syn-rift strata filling one of several small fault bounded basins imaged on seismic data in the eastern Mentelle Basin (Figure 3a). Unit IIb is interpreted to be nearshore facies deposited on a subsiding coast, with increasing marine incursions near the top that culminated in deposition of the glauconitic sandstone in unit IIa. A prominent reflector from the boundary between lithostratigraphic units IIc and IIb at Site U1515 can be traced into the western Mentelle Basin, where it manifests as an undated unconformity below the basalt flows at the top of the faulted syn-rift strata (Figure 3c).

IODP Sites U1514 (water depth $3850 \mathrm{~m}$ ) and U1516 (2675 m) are respectively located in the northern and southern parts of the central Mentelle Basin, where the basin is structurally and bathymetrically deepest (Figure 1). Drilling at both sites encountered up to $400 \mathrm{~m}$ of Pleistocene to Miocene or late Eocene ooze (lithostratigraphic unit I) overlying Eocene to Paleocene chalk that grades downward into claystone (lithostratigraphic unit II at Site U1514, and subunits Ib and Ic at Site U1516) (Figure 4). At Site U1514, lithostratigraphic unit II conformably overlies a Paleocene through Albian claystone and silty claystone (unit III). At Site U1516, a detachment separates the base of the Paleocene claystone (subunit Ic) from an underlying Turonian cherty chalk and claystone (unit II). Unit II conformably overlies a Cenomanian through Albian succession of chalk and claystone (units III and IV). Benthic foraminifera indicate middle bathyal (600-1000 m) to lower bathyal (1000-2000 m) water depths for deposition of units I and II, and bathyal water depths for unit III at Site U1514. Bathyal water depths are indicated throughout the succession cored at Site U1516.

This article is protected by copyright. All rights reserved. 
IODP Site U1513 is located at $2788 \mathrm{~m}$ water depth on the western edge of the Mentelle Basin, overlying the eastern margin of the Naturaliste Plateau (Figures 1 and 3c). Six lithostratigraphic units are identified in a composite stratigraphic section created from five clustered boreholes, extending to a maximum depth of $774 \mathrm{mbsf}$ (Figure 4). The upper $65 \mathrm{~m}$ of strata consists of Pleistocene through late Miocene dominantly calcareous ooze (lithostratigraphic unit I). A depositional hiatus associated with a hardground separates unit I from an underlying $181 \mathrm{~m}$ thick Cenomanian through Campanian calcareous ooze and chalk interval (lithostratigraphic unit II). Benthic foraminifera indicate bathyal and middle bathyal water depths for deposition of units I and II, respectively. Unit II is underlain by a $209 \mathrm{~m}$ thick Cenomanian through Albian clay and claystone deposited in middle bathyal to bathyal water depths (lithostratigraphic unit III, $22 \mathrm{~m}$ thick; and unit IV, $187 \mathrm{~m}$ thick). The clay and claystone beds conformably overlie a $235 \mathrm{~m}$ thick lithic-rich clayey siltstone and sandstone interval ranging from early Aptian to earliest Hauterivian in age that contains glauconite, pyrite, shell fragments, plant debris, and abundant volcanic mineral grains and clasts (lithostratigraphic unit V) (Huber et al., 2019; Lee et al., 2020). A similar lithostratigraphic unit, rich in volcanic clasts and with a ferruginous detrital claystone at its base, was encountered at nearby DSDP Site 258 (Davies et al., 1974). These strata are interpreted to be epiclastic deposits comprised primarily of material weathered from nearby (but perhaps not immediately local) volcanic sources. Unit V matches the definition of secondary (epiclastic) volcaniclastic deposits used by many authors (Fisher, 1961; Mulder, 2001), but more recent usage has excluded epiclastic deposits from the volcaniclastic classification (McPhie et al., 1993; Manville et al., 2009). Following the more recent usage, we refer to unit $\mathrm{V}$ in this paper as a volcanogenic clastic, or simply an epiclastic succession. Taken together, the sedimentary structures, trace fossils, benthic foraminifera, and palynomorphs indicate deposition in shallowing water depths downward in the section from upper bathyal to neritic for unit V. An $83 \mathrm{~m}$ thick interval of interbedded basalt flows and volcaniclastic flows recording at least five eruption episodes (lithostratigraphic unit VI) lies below unit V, but the total thickness of unit VI is undetermined (Figure 4) (Huber et al., 2019; Tejada et al., 2020). The entire volcanic and volcanogenic clastic interval (units VI and V) was hydrothermally altered prior to deposition of unit IV, but the least (weakly to moderately) altered samples from Unit VI have $\mathrm{SiO}_{2}$ contents (43.7-52.5 wt\%), total alkali contents (2.11-2.38 $\mathrm{wt} \%$ ), and $\mathrm{Zr} / \mathrm{Y}$ and $\mathrm{Zr} / \mathrm{Nb}$ ratios typical of tholeiitic basalts (Figures $5 \mathrm{a}, \mathrm{b}$ ). The Unit VI flows with the lowest total alkali contents appear to be less altered than either the Bunbury Basalt or other mafic rocks recovered by previous dredging on the Naturaliste Plateau (Figures 5a, c). The basalt flows in Unit VI are undated, but the magnetostratigraphic age of unit V spans chrons M10Nn.1n to M0r (131 to $121 \mathrm{Ma}$ ) (Huber et al., 2019; Lee et al., 2020). The underlying basalt flows of unit VI thus predate the end of chron M10Nn.1n. This gives a minimum age of $131 \mathrm{Ma}$ (earliest Hauterivian) for their emplacement, indicating that the flows were likely contemporaneous with the Bunbury Basalt eruptions (130-137 Ma; Olierook et al., 2016).

\section{Analysis: New Constraints on Breakup, Basalt Petrogenesis, Extension, and Subsidence}

\subsection{Stratigraphic record of the rift to drift transition on the Southwest Australian margin}

The basalt flows of lithostratigraphic unit VI at Site U1513 lie on top of the breakup unconformity imaged in seismic reflection data (Figure 3c), as envisioned by Maloney et al. (2011). The seismic unconformity can be traced into the eastern Mentelle Basin where it is equivalent or nearly equivalent to the Valanginian breakup unconformity encountered at Site

This article is protected by copyright. All rights reserved. 
U1515. Pillow structures present in some flows and oxidation of most flows suggest eruption in a nearshore shallow water to subaerial environment (Huber et al., 2019a; Tejada et al., 2020). We interpret the basalt flows to have been erupted near sea level during the last stages of extension on this part of the southwestern Australian margin, immediately after seafloor spreading had begun on the Perth Abyssal Plain between magnetochrons M11r and M11n (133-132 Ma) but before the onset of seafloor spreading west of the Naturaliste Plateau between magnetochrons M5n and M3n (126-124 Ma). The overlying epiclastic sequence of unit V contains volcanic mineral grains and lithic fragments interpreted to be eroded from volcanic rocks on the Naturaliste Plateau or perhaps further south on the conjugate Antarctica margin, which were reworked and deposited in shallow marine to upper bathyal conditions (Lee et al., 2020) as the Perth Abyssal Plain spreading center migrated westward along the northern margin of the plateau. A similar interpretation was made of the volcaniclastic strata encountered at nearby DSDP Site 258 (Davies et al., 1974). The breakup unconformity imaged on seismic data below the basalt flows is thus interpreted to be associated with the onset of seafloor spreading on the Perth Abyssal Plain, in keeping with previous interpretations (Borissova, 2010; Hall et al., 2013). If anomaly M1 $\mathrm{n}$ is accepted as the oldest seafloor spreading anomaly on the Perth Abyssal Plain (Markl, 1974; Robb et al., 2005), then breakup must have occurred after chron M11r (133 Ma, Table 1). As noted in section 3, the basalt flows encountered above the breakup unconformity at IODP Site U1513 must predate chron M10Nn.1n (131 Ma). This implies a narrowly constrained and approximately coeval age of 132-133 Ma for the Perth Basin breakup event and emplacement of the Site U1513 basalts.

The onset of seafloor spreading west of the Naturaliste Plateau (the Naturaliste Plateau breakup event) occurred during deposition of the upper part of lithostratigraphic unit V. We associate this breakup event with a conformable upward transition from clayey siltstone (subunit 3 ) to silty claystone (subunit 2) and corresponding decreases in the abundance of fossils, bioturbation, and volcanic material (Huber et al., 2019; Lee et al., 2020). Benthic foraminifera indicate deepening of the seafloor from neritic to upper bathyal depths during this interval, followed by subsidence to at least middle bathyal water depth during Aptian time between deposition of unit $\mathrm{V}$ and the marine claystones of unit IV. The transition between subunits 2 and 3 is near the boundary between chrons M5n and M3r (Lee et al., 2020), indicating an age of 126 Ma (Table 1) for the Naturaliste Plateau breakup event (in agreement with the age range indicated by the seafloor spreading anomalies).

\subsection{Constraints on melting conditions for the Naturaliste Plateau basalts}

Several of the basalt flows from Site U1513 have relatively high $\mathrm{MgO}(8.7-11.8 \mathrm{wt} \%)$ and low $\mathrm{TiO}_{2}(0.31-0.60 \mathrm{wt} \%)$ contents that are respectively suggestive of relatively high degrees of melting and low degrees of fractionation. These primitive composition basalts $(\mathrm{MgO}$ $>8 \mathrm{wt} \%$ ) provide the first constraints on melting conditions and primary magma composition for Naturaliste Plateau volcanic rocks. Petrogenetic modeling based on major element data from the least altered high-MgO sample, using PRIMACALC_2.10 with COMAGMAT3.72 (Kimura and Ariskin, 2014), indicates a primary magma composition with $\mathrm{Mg} \#=0.77$ and equilibrium olivine forsterite content Fo $=92 \%$. This primary magma can be generated from approximately $25 \%$ melting of a lherzolite source at $1.5 \mathrm{GPa}$ (approximately $50 \mathrm{~km}$ depth), with modeled magmatic temperatures of $1369-1413{ }^{\circ} \mathrm{C}$ (Figure 6, Table 3). These magmatic temperatures are equivalent to mantle potential temperatures of $1380-1410{ }^{\circ} \mathrm{C}$, with a nominal value of $1400{ }^{\circ} \mathrm{C}$, estimated using OBS1 (Kimura and Kawabata, 2015). Except for the most altered samples (LOI

This article is protected by copyright. All rights reserved. 
$>5 \mathrm{wt} \%$ ), the major element and trace element compositions of the Site U1513 basalts overlap with the compositional fields of basalts encountered at ODP Site 1140 on the Kerguelen Plateau (e.g., Figures 5b and 5c). The origin of the Site 1140 basalts has been interpreted to be mixing of Kerguelen plume and Southeast Indian Ocean Ridge depleted mantle sources (Dosso et al., 1988; Wallace et al., 2002; Weis and Frey, 2002). We infer a similar origin for the Naturaliste Plateau basalts.

\subsection{Crustal thinning and the amount and distribution of extension}

Paleo drainage patterns determined from detrital zircons indicate that the western Australian margin was a relatively flat peneplain in Early Jurassic time (Sircombe and Freeman, 1999). Assuming Airy isostasy, a pre-rift elevation at sea level, and post-rift thermal reequilibration of the rifted lithosphere, the minimum amount of thinning of the crust, $\Delta \mathrm{H}$, can be determined from the present depth of the breakup unconformity:

$$
\Delta H=W D \frac{\left(\rho_{m}-\rho_{w}\right)}{\left(\rho_{m}-\rho_{c}\right)}+S T \frac{\left(\rho_{m}-\rho_{s}\right)}{\left(\rho_{m}-\rho_{c}\right)}
$$

where WD is water depth (2788 $\mathrm{m}$ and $850 \mathrm{~m}$ at Sites U1513 and U1515, respectively), ST is strata thickness above the unconformity ( $800 \mathrm{~m}$ and $335 \mathrm{~m})$, and $\rho_{\mathrm{m}}, \rho_{\mathrm{c}}, \rho_{\mathrm{s}}$, and $\rho_{\mathrm{w}}$ are the densities of the mantle $\left(3300 \mathrm{~kg} \mathrm{~m}^{-3}\right)$, crust $\left(2800 \mathrm{~kg} \mathrm{~m}^{-3}\right)$, post-rift strata $\left(2300 \mathrm{~kg} \mathrm{~m}^{-3}\right)$, and water $\left(1000 \mathrm{~kg} \mathrm{~m}^{-3}\right)$ (e.g., Lee et al., 2019). This indicates that the crust has been thinned by at least $14 \mathrm{~km}$ and $5 \mathrm{~km}$ at Sites U1513 and U1515, respectively. The thickness of the crust prior to extension is unknown, but is likely to have been similar to the unextended crust beneath either the Yilgarn Craton east of the Perth Basin onshore, or the relatively unextended Yallingup Shelf that lies between the Perth and Mentelle Basins. Gravity, seismic refraction, and receiver function studies show the thickness of the crust in the western Yilgarn Craton typically ranges between 32 to $38 \mathrm{~km}$, and may locally be as thick as $43 \mathrm{~km}$ (Dentith et al., 2000; Kennett et al., 2011; Olierook et al., 2016; Reading et al., 2003; Saygin and Kennett, 2012). The thickness of the crust beneath the Yallingup Shelf is similar to that of the craton, ranging from 30-35 km (Direen et al., 2007; Olierook et al., 2016). Taking the extremes (30 and $43 \mathrm{~km}$ ) as indications of the pre-rift crust thickness suggests that the crust has been thinned a minimum of 33 to $44 \%$ at Site U1513 in the western Mentelle Basin, and by 12 to $16 \%$ at Site U1515 in the eastern Mentelle Basin. If thinning is attributed entirely to extension, the corresponding extension factors are $\beta=1.5$ to 1.8 at Site U1513 and $\beta=1.1$ to 1.2 at Site U1513. Similar amount of extension, $\beta$ $=1.4-1.6$, were estimated by Olierook et al. (2016) for the southern Perth Basin and the Naturaliste Plateau, although they estimate higher values $(\beta=3)$ in the central Mentelle Basin. However, it need be recognized that additional alterations of the crust thickness, beyond extensional thinning, likely occurred during rifting and affected the isostatic state of the margin. Specifically, some portion of crust thinning was likely accommodated by erosion during uplift in the early stages of rifting (e.g., Falvey, 1974). Additionally, it is possible that the base of the crust was inflated by magmatic intrusion (e.g., Mutter et al., 1982). The margin lacks the large potential fields highs typically associated with magmatic underplating or intrusion, and so significant magmatic inflation of the crust is unlikely. The amount and spatial distribution of erosion of the pre-rift crust beneath the southwestern Australian marginal basins is unknown, and so the amount of crustal thinning by extension given above may be over-estimated.

This article is protected by copyright. All rights reserved. 


\subsection{Subsidence and sedimentation history}

The highest sedimentation rates encountered in the boreholes are in lithostratigraphic unit $\mathrm{V}$ at Site U1513 in the western Mentelle Basin, above the eastern flank of the Naturaliste Plateau (Figure 7). This $250 \mathrm{~m}$ thick unit was deposited between 131 to $121.8 \mathrm{Ma}$, encompassing the time interval between the Perth Abyssal Plain and Naturaliste Plateau breakup events. Benthic foraminifera indicate water depths increased only slightly during this time, from neritic to upper bathyal (Lee et al., 2020). The amount of tectonic subsidence, $\mathrm{S}_{\mathrm{t}}$, during this period is estimated from the change in the depth to the base of the unit after correcting for sediment and water loading (Steckler and Watts, 1978):

$$
S_{t}=T_{u}\left(\frac{\rho_{m}-\rho_{s}}{\rho_{m}-\rho_{w}}\right)+\Delta S F-\Delta S L\left(\frac{\rho_{m}}{\rho_{m}-\rho_{w}}\right)
$$

where $T_{u}$ is the uncompacted thickness of the unit ( $273 \mathrm{~m}$ : Lee et al., 2020 supplemental data), $\Delta \mathrm{SL}$ and $\Delta \mathrm{SF}$ respectively are the changes in eustatic sea level (60 m; Haq, 2014) and seafloor depth that occurred during deposition of the unit, and $\rho_{\mathrm{m}}, \rho_{\mathrm{s}}$, and $\rho_{\mathrm{w}}$ are the densities of the mantle, sediments, and water, respectively. $\Delta \mathrm{SF}$ is nominally estimated to be $300 \mathrm{~m}$ (the distance between the midpoints of the neritic and upper bathyal depth ranges), with a maximum of $600 \mathrm{~m}$ (innermost neritic to lowermost upper bathyal). Using the densities from the previous section, equation 2 indicates 333 to $633 \mathrm{~m}$ of tectonic subsidence during deposition of unit $\mathrm{V}$, which corresponds to 1650 to $3030 \mathrm{~m}$ of crustal thinning (equation 1). The densities used here are representative of the lithosphere after thermal re-equilibration. The proximity of the Kerguelen plume and Perth Abyssal Plain spreading ridge and the relatively high melting temperature estimated for the unit VI basalts suggest hotter conditions at the time of breakup. Assuming an accordingly lower mantle density of $3100 \mathrm{~kg} \mathrm{~m}^{-3}$ and a higher crust density of $2900 \mathrm{~kg} \mathrm{~m}^{-3}$ (representing a more mafic crust) results in a similar amount of tectonic subsidence (315 to 615 $\mathrm{m}$ ) as the cooler model, but much larger estimates of crustal thinning (3612 to $6762 \mathrm{~m}$ ). In either case (warm or cool lithosphere), the amount of crustal thinning inferred to have occurred between the Perth Abyssal Plain and Naturaliste Plateau breakup events is less than the total amount of thinning estimated to have occurred on the margin in the previous section $(14 \mathrm{~km})$. We conclude that 50-75\% of the thinning at Site U1513 took place prior to the Perth Abyssal Plain breakup event and was most likely coeval with extension in the Perth Basin. We attribute most of this crustal thinning to extensional tectonism, but we note that non-extensional thinning of the lithosphere prior to breakup is also likely to have occurred due to erosion at the top and possibly thermal thinning of the base of the lithosphere. The amounts of these types of thinning are unknown.

Despite $14 \mathrm{~km}$ or more of cumulative crustal thinning, the seafloor at Site U1513 remained at neritic depths between the two breakup events on the margin and at upper bathyal depths for 3 to $5 \mathrm{Myr}$ following the Naturaliste Plateau breakup event (during deposition of the upper part of unit $\mathrm{V}$ ). The basalts at the top of unit $\mathrm{V}$ erupted near the seafloor and underwent no more than about $630 \mathrm{~m}$ of tectonic subsidence during this time. The one-dimensional pure shear thinning model of McKenzie (1978) predicts more than $1200 \mathrm{~m}$ of subsidence at Site U1513 using the densities above, the previously estimated extension factor $\beta=1.9$, and assuming a 125 $\mathrm{km}$ thick pre-rift lithosphere and a mantle potential temperature of $1300{ }^{\circ} \mathrm{C}$. We attribute the approximately $570 \mathrm{~m}$ deficit in syn-rift and early post-breakup subsidence on the Naturaliste Plateau to lateral (southward) flow of heat from the Perth Abyssal Plain spreading ridge, which was migrating westward along the northern margins of the Mentelle Basin and Naturaliste

This article is protected by copyright. All rights reserved. 
Plateau during this time. Alternatively (or in addition), heat from the nearby Kerguelen plume may have kept the margin elevated during rifting. The plume moved southwestward away from the Australian margin after breakup, so its thermal effect on the margin through time would have been similar to that of the Perth Abyssal Plain spreading ridge. Sedimentation rates at Site U1513 were low or zero for approximately 20 Myr following the Naturaliste Plateau breakup event as the margin cooled and subsided to middle bathyal depths (Figure 7).

The post-rift depositional hiatus at Site U1513 was followed by a second phase of rapid sedimentation between about $110 \mathrm{Ma}$ and at least $82 \mathrm{Ma}$ (Figure 7). The beginning of the second phase of rapid sedimentation at Site U1513 approximately coincides with the ridge jump at 108 Ma that transferred Gulden Draak and Batavia Knolls from the Indian Plate to the Australian Plate (Gibbons et al., 2012; Whittaker et al., 2016; Williams et al., 2013) (Figure 2e). The second phase of rapid sedimentation may have begun as late as 105 Ma at Sites U1514 and U1516, approximately corresponding with the onset of rifting on the southern margin between Australia and Antarctica (Figure 2f). Sedimentation rates slowed at Sites U1514 and U1516 after about 88 $\mathrm{Ma}$, approximately coinciding with the transition to slow seafloor spreading and/or mantle exhumation on the southern margin by $84 \mathrm{Ma}$ (Figure $2 \mathrm{~g}$ ).

Slow sedimentation continued through the Paleogene, interrupted by periods of relatively rapid sedimentation at Site U1514 between 60-55 Ma and at Sites U1514 and U1516 between 47 to $32 \mathrm{Ma}$ (Figure 7). The onset of the latter episode of rapid sedimentation coincides with the transition from slow spreading to normal seafloor spreading on the southern margin between 47$42 \mathrm{Ma}$ (Figure 2f). However, we consider it unlikely that either of the Paleogene periods of rapid sedimentation were a direct result of subsidence produced by extension on the southern margin, because the Australian and Antarctic plates presumably became decoupled after slow spreading was established at about $84 \mathrm{Ma}$. We consider it more likely that changes in the sedimentation rates on the southwestern margin during the Paleogene are a result of changes in carbonate productivity, perhaps influenced by changing ocean circulation patterns as the Southern Ocean opened. Sediment accumulation rates decreased again after about $32 \mathrm{Ma}$ and remained relatively low until $15 \mathrm{Ma}$ at Sites U1513 and U1514 until the present time (increasing slightly after the end of the Miocene Epoch). This Oligocene through middle Miocene interval of low sedimentation rates correlates with an upper Miocene unconformity at DSDP Sites 258 and 264 on the Naturaliste Plateau, which Luyendyk and Davies (1974) attributed to seafloor erosion and non-deposition following establishment of a strong circumpolar current after opening of the Australia-Antarctic seaway during the Oligocene Epoch (Kennett et al., 1972). The sedimentation rate increased slightly at Sites U1513 and U1514 after about $15 \mathrm{Ma}$, as has been observed globally (Molnar, 2004), and more dramatically at Site U1516 (Figure 7).

\section{Discussion: Implications for Rifting and Magmatism on the Southwest Australian Margin}

\subsection{Tectonic evolution and subsidence}

The tectonic, stratigraphic, and magmatic evolution of the southwestern Australian continental margin is summarized schematically in Figure 8. The Late Jurassic through Early Cretaceous rifting that led to opening of the eastern Indian Ocean followed the trend of older north to north-northwest striking rift basins that initially formed during early to middle Permian extension (Veevers, 2006). A period of relative tectonic quiescence and slow thermal subsidence followed, during which time the western Australian margin remained near sea level, as

This article is protected by copyright. All rights reserved. 
evidenced in the Perth Basin by Early Triassic shallow marine beds grading upward to Early Triassic through Early Jurassic deltaic deposits, coal measures, and red beds (Hall et al., 2013; Norvick, 2004; Veevers, 2006; Yeates et al., 1987) (Figure 8a). Extension was renewed during Middle Jurassic time, accompanied by faulting and accumulation of Late Jurassic through earliest Cretaceous syn-rift fluvial and deltaic strata within half-grabens, many of which formed on reactivated Permian faults (Bradshaw et al., 2003; Norvick, 2004). Seismic profiles show abundant faults below the breakup unconformity on the Naturaliste Plateau and in the Perth and Mentelle Basins (Borissova, 2002; Borissova et al., 2010; Hall et al., 2013; Maloney et al., 2011) (Figure 3), indicating that Jurassic through Early Cretaceous extension was accommodated by normal faulting that spanned the breadth of the southwestern Australian margin. Extension was focused most strongly within the central and eastern Mentelle Basin and in the outboard parts of the Perth Basin, where the crust was thinned by factors of $\beta \approx 1.7-3$ and 1.2-1.6, respectively (Olierook et al., 2016, and this paper). We interpret the Late Jurassic to earliest Cretaceous fluvio-lacustrine sequence (lithostratigraphic unit IIc) at Site U1515 to be part of the syn-rift strata that filled one of the several fault-bounded sub-basins within the emergent rift. Regional uplift coeval with faulting and filling of the sub-basins is indicated by 1) erosional truncation of fault blocks by the breakup unconformity on the flanks of the rift basins (Figure 3) (Borissova, 2002; Borissova et al., 2010; Crostella and Backhouse, 2000; Hall et al., 2013); and 2) the ages of detrital zircons in the lower part of the syn-rift strata in the Perth Basin, which indicate dominantly local sources from within the Proterozoic Pinjarra and Albany-Fraser orogens that form the basement beneath the Australian margin (Sircombe and Freeman, 1999). The upper syn-rift strata are missing in the Perth Basin due to Early Cretaceous erosion at the time of breakup (Bradshaw et al., 2003) (Figure 8b). The Late Jurassic syn-rift fluvio-lacustrine deposits at Site U1515 transition upward into marine strata (units IIb and IIa), indicating subsidence and marine transgression in the eastern Mentelle Basin beginning in late Valanginian time following breakup and the onset of seafloor spreading on the Perth Abyssal Plain at $132 \mathrm{Ma}$ (Figure 8c).

Emplacement of the Bunbury Basalt in the Perth Basin (137-130 Ma), the basalt flows at Site U1513 (>131 Ma), and the mafic rocks dredged from the margins of the Naturaliste Plateau (132-128 Ma; Direen et al., 2017) were synchronous with seafloor spreading on the Perth Abyssal Plain, but preceded the onset of spreading west of the Naturaliste Plateau. Seismic profiles show many faults in the western Mentelle Basin extend upward into Barremian strata (Borissova, 2002; Borissova et al., 2010), consistent with ongoing extension on this portion of the southwestern Australian margin between the onset of spreading on the Perth Abyssal Plain during the late Valanginian at 133-132 Ma and the onset of spreading west of the Naturaliste Plateau during the early Barremian at $126 \mathrm{Ma}$ (Gibbons et al., 2012; Williams et al., 2013) (Figure 8d). The margin transitioned from volcanically active to inactive between 132 and 126 Ma, with the volcanic sequence deposited atop the breakup unconformity being eroded and redeposited in the volcanogenic clastic succession on the Naturaliste Plateau (Figure 3c).

Shallow water and/or subaerial emplacement of the basalts at Site U1513, the transition from terrestrial to shallow marine deposition across the stratal equivalent of the unconformity in unit IIb at Site U1515, and the recovery of similar shallow water upper Jurassic strata below the unconformity in the Perth Basin (Crostella and Backhouse, 2000) indicate that the entire southwestern Australian margin was near sea level at the time seafloor spreading began on the Perth Abyssal Plain. Benthic foraminifera and sedimentary features in the epiclastic section overlying the basalt flows at Site U1513 show that the Naturaliste Plateau remained at or near neritic depths following the Perth Abyssal Plain breakup event at 133-132 Ma, and at upper

This article is protected by copyright. All rights reserved. 
bathyal depths for at least $3 \mathrm{Myr}$ following the Naturaliste Plateau breakup event at $126 \mathrm{Ma}$. The margin underwent no more than about $630 \mathrm{~m}$ of tectonic subsidence between the two breakup events, in spite of ongoing extension. The lack of greater amounts of subsidence during the final stages of rifting and immediately afterward can be attributed to the proximity of either i) the Perth Abyssal Plain spreading ridge, which was migrating westward along the northern edges of the Mentelle Basin and Naturaliste Plateau between $132 \mathrm{Ma}$ and $124 \mathrm{Ma}$, or ii) the Kerguelen plume, which was moving southwestward away from the margin during this time. The approximately $1400{ }^{\circ} \mathrm{C}$ mantle potential temperature indicated by petrogenetic modeling of the basalt compositions at Site U1513 supports the presence of a warm buoyant plume head beneath the rift at the time of breakup.

The onset of a depositional hiatus and the end of deposition of the volcanogenic clastic strata (unit V) on the Naturaliste Plateau occurred at chron M0r time (Lee et al., 2020), coinciding with a westward jump of the Perth Basin spreading ridge away from the Australian margin (Gibbons et al., 2012). We infer that thermal subsidence of the Naturaliste Plateau began at this time, as the marine claystones of unit IV at Site U1513 indicate that the eastern Naturaliste Plateau had reached at least middle bathyal depths by early Albian time (110 Ma) (Figure 8e). We attribute the reduction in sedimentation rate after deposition of unit $\mathrm{V}$ to the increased depth of the plateau and the corresponding reduction in the supply of clastic sediments weathered from the subsiding volcanic terranes. Sediment from potential distal sources in Greater India and Australia would have been prevented from reaching the Naturaliste Plateau by the newly opened seaway to the west and by the subsiding Mentelle Basin to the east. The water depth in the central Mentelle Basin (Sites U1514 and U1516) is loosely constrained to have been within the broad bathyal depth range in early Albian time.

Following the depositional hiatus at Site U1513 a period of relatively rapid sedimentation occurred on the Naturaliste Plateau (Site U1513) and in the central Mentelle Basin (U1514 and U1516) beginning between 110-100 Ma and lasting to at least $82 \mathrm{Ma}$ (Figure 7). The beginning of this period of rapid sedimentation was coincident with a westward jump of the Indian Ocean spreading ridge at $108 \mathrm{Ma}$ and with the onset of rifting on the southern Australian margin. The high sedimentation rates during this period may reflect ongoing thermal subsidence on the margin after breakup between Australia and Greater India, possibly with increased sediment input from the southern rift, or it may reflect subsidence related to extension on the southern margin. The latter possibility is supported by the modest decrease in sedimentation rates after about $88 \mathrm{Ma}$ at Sites U1515 and U1516, which may indicate decreased coupling between the Australian and Antarctic plates as slow spreading developed on the southern margin. Another interval of relatively rapid sedimentation in the central Mentelle Basin (Sites U1514 and U1516) began at about $47 \mathrm{Ma}$, when normal seafloor spreading was established and final separation occurred between Australia and Antarctica (this was preceded at Site U1514 by a short interval of rapid sedimentation between 60-55 Ma). The periods of rapid sedimentation beginning at 100 $\mathrm{Ma}, 60 \mathrm{Ma}$, and $47 \mathrm{Ma}$ correlate with tectonic events on the southern margin, but we note that the post-Aptian strata are carbonate rich and so thickness changes are not necessarily indicative of subsidence. The post-Aptian changes in sedimentation rate may be due to increased productivity in the water column that resulted from changes in ocean circulation patterns that occurred as the new seaway opened between Australian and Antarctica. Except for accumulation of about $250 \mathrm{~m}$ of carbonates in the southern part of the central Mentelle Basin (Site U1516), the margin has experienced little deposition since late Oligocene time as it subsided to its modern lower bathyal to abyssal (>2000 m) water depths (Figure $8 f$ ).

This article is protected by copyright. All rights reserved. 
5.2 Petrogenesis and distribution of syn-rift basalts and relation to the Kerguelen Plume

Petrogenetic modeling suggests that the most primitive basalts recovered at IODP Site U1513 were generated from approximately $25 \%$ melting of a lherzolite source at $1.5 \mathrm{GPa}$ (approximately $50 \mathrm{~km}$ depth) and a mantle potential temperature of about $1400{ }^{\circ} \mathrm{C}$ (with estimated primary magma temperatures ranging from $1369-1413^{\circ} \mathrm{C}$ ). This temperature is high compared to the global average, which typically ranges from $1250{ }^{\circ} \mathrm{C}$ to $1350{ }^{\circ} \mathrm{C}$ (Gudfinnsson and Presnall, 2005; Kimura and Kawabata, 2015; McKenzie and Bickle, 1988; McKenzie et al., 2005; Presnall et al., 2002), although global average potential temperatures as high as $1420{ }^{\circ} \mathrm{C}$ have been suggested (Herzberg et al., 2007; Putirka, 2005). The relatively high potential temperature seems indicative of the presence of an active or recently active plume at the time of breakup. The estimated mantle temperature is $\geq 100^{\circ} \mathrm{C}$ lower than expected for the axis of a plume, but within the expected range for a broad plume head (Campbell and Griffiths, 1990; White and McKenzie, 1995). The melting conditions are thus consistent with either a large diameter Kerguelen plume head beneath the northeastern Indian Ocean during the Early Cretaceous Period (Direen et al., 2017; Olierook et al., 2016; Olierook et al., 2017; Storey et al., 1989), or with multiple limbs from a fragmented or dismembered plume (Coffin et al., 2002).

The Bunbury Basalt and the basalt flows encountered in the western Mentelle Basin at IODP Site U1513 represent late syn-rift and early post-rift magmatism that, although geographically widespread, has a relatively small net thickness for plume-related volcanism. The moderately high mantle potential temperature inferred from the Naturaliste Plateau basalts (1400 ${ }^{\circ} \mathrm{C}$ ) suggests a larger thickness of melt should have been produced during earlier stages of rifting, particularly in the highly extended central Mentelle Basin (where $\beta>3$ ) (e.g., McKenzie and Bickle, 1988). Possible evidence of such earlier syn-rift magmatism are high-amplitude seismic reflectors imaged within the thick undrilled stratified interval below the lowermost (Valanginian) breakup unconformity in the central and western Mentelle Basin (Figure 9). These highamplitude reflectors could be produced by basalt flows interbedded within the Late Cretaceous syn-rift strata that has been previously interpreted to fill the fault bounded rift basins below the Valanginian breakup unconformity (Borissova et al., 2010; Maloney et al., 2011). Seismic velocities in this interval average about $6 \mathrm{~km} \mathrm{~s}^{-1}$ (Maloney et al., 2011), which is high compared to most siliclastic rocks, which typically range from about 2.5 to $5.0 \mathrm{~km} \mathrm{~s}^{-1}$ (Castagna et al, 1985). The seismic velocity of basalt typically ranges from about 5.2 to $6.5 \mathrm{~km} \mathrm{~s}^{-1}$ (Christensen and Stanley, 2003). Assuming a basalt velocity of $6.5 \mathrm{~km} \mathrm{~s}^{-1}$ (appropriate for low porosity flows or sills), volume averaging of the velocities suggests $67-88 \%$ of the material filling the rift basins below the Valanginian unconformity in the central and western Mentelle Basin could be basaltic. Substantially larger volumes of basalt (up to 100\%) may be implied if the basalt velocity is lower than $6.5 \mathrm{~km} \mathrm{~s}^{-1}$, although this seems unlikely given the similarity of the deep reflections in the western Mentelle Basin with those imaged within the Permian and Jurassic syn-rift sedimentary strata further east on the margin in the Perth Basin (e.g., Borissova et al., 2010).

Alternatively, little basalt (potentially none) below the Valanginian breakup unconformity may be implied if the high velocity in the syn-rift clastic sediments is due to hydrothermal cementation, as is observed in the volcaniclastic sediments in unit $\mathrm{V}$ and in the interbedded flows of unit VI at IODP Site U1513. In such a case, the Bunbury Basalt and the basalts of the western Mentelle Basin and Naturaliste Plateau may represent minor late-stage magmatism that occurred immediately prior to breakup on an otherwise amagmatic segment of the western Australia rifted margin. This is consistent with the model of Olierook et al. (2016),

This article is protected by copyright. All rights reserved. 
who suggested that the Bunbury Basalt originated from decompression melting of fertile domains in the upper mantle that were themselves products of older metasomatic episodes. However, although melting of fertile components may be a sufficient explanation for the Bunbury Basalt, the relatively high mantle temperature inferred from the Site U1513 basalts indicates some influence from a hot plume. This favors a hybrid interpretation, in which the Bunbury Basalt in the moderately extended southern Perth Basin is a result of melting of fertile domains within a metasomatized lithospheric mantle, whereas the basalts of the more highly extended central and western Mentelle Basin may be products of decompression melting of a warm sub-lithospheric mantle plume head or plume limb.

\section{Summary}

IODP Expedition 369 drilled four sites on the southwestern Australian continental margin. At Site U1513, located in the western Mentelle Basin above the eastern flank of the Naturaliste Plateau, drilling penetrated into Early Cretaceous interbedded basalt flows and volcaniclastic layers that lie immediately above the seismically imaged breakup unconformity. Sites U1514 and U1516, located in the central Mentelle Basin, penetrated into an Early Cretaceous (Albian) post-rift marine claystone unit. Drilling at Site U1515, near the eastern edge of the Mentelle Basin, penetrated through the post-rift sequence and into late syn-rift lacustrine deposits. Drilling shows the seismically imaged breakup unconformity on the Naturaliste Plateau and in the western Mentelle Basin to be equivalent to the late Valanginian breakup unconformity that is present in the Perth Basin, which extends for $1000 \mathrm{~km}$ along the western Australian margin beneath the continental shelf. The late Valanginian unconformity marks the onset of seafloor spreading on the Perth Abyssal Plain, which is inferred to have begun between chrons M11r and M11n (133-132 Ma). In the western Mentelle Basin/Naturaliste Plateau (Site U1513), the Valanginian unconformity is overlain by basalt flows and interlayered volcaniclastic beds that were sampled in-situ for the first time during IODP Expedition 369. Petrogenetic modeling indicates these basalts formed by approximately $25 \%$ melting of a lherzolite mantle source at 1.5 $\mathrm{GPa}$ and with a mantle potential temperature of $1400{ }^{\circ} \mathrm{C}$. This moderately high mantle potential temperature is most easily accounted for by the presence of a large Kerguelen plume head beneath the eastern Indian Ocean at the time of breakup, although the trace element geochemistry and melting trends also suggest involvement of a mid-ocean ridge component. The magnetostratigraphy of the overlying strata show that the basalt flows at Site U1513 predate the end of chron M10Nn.1n (131 Ma). The breakup unconformity below the basalts is interpreted to have formed when seafloor spreading began on the Perth Abyssal Plain, no earlier than chron M11r (133 Ma). This implies that the flows encountered at Site U1513 were emplaced between 132-133 Ma, immediately after (or synchronous with) the onset of seafloor spreading on the Perth Abyssal Plain and contemporaneous with the Bunbury Basalt found in the southern Perth Basin. In the eastern Mentelle Basin at Site U1515, breakup on the Perth Abyssal Plain manifests as a rapid conformable upward transition from Late Jurassic to earliest Cretaceous syn-rift fluvio-lacustrine strata deposited in a fault bounded rift basin into transgressive marine strata deposited after breakup.

At Site U1513, the basalt flows are overlain by a $235 \mathrm{~m}$ thick epiclastic sequence deposited mostly at shelf depths that contains abundant weathered volcanic materials, presumably sourced from local volcanic edifices. These strata demonstrate that the eastern Naturaliste Plateau remained at shallow depths for 3-5 million years following breakup on the Perth Abyssal Plain. The uppermost part of the volcanogenic epiclastic strata contains marine

This article is protected by copyright. All rights reserved. 
silty claystone that was deposited in upper bathyal depths. This is interpreted to be the lower part of the post-rift sequence, deposited after the second breakup event on the margin at $126 \mathrm{Ma}$ that marked final separation of Greater India from Australia and the onset of seafloor spreading to the west of the Naturaliste Plateau.

Pillow structures and oxidation show that the basalt flows on the eastern Naturaliste Plateau and in the western Mentelle Basin (Site U1513) were erupted subaerially or in shallow water, indicating that the southwestern Australian margin was near sea level when seafloor spreading began on the Perth Abyssal Plain. The Naturaliste Plateau remained at shelf depths during the 6-9 Myr period between breakup on the Perth Abyssal Plain to the north (132-133 $\mathrm{Ma}$ ) and final breakup with Greater India to the west (124-126 Ma), and subsided to only upper bathyal depths during the 3-5 Myr period after the final breakup event. The lack of greater subsidence during this late syn-rift and early post-rift period is attributed to heat from the nearby Perth Abyssal Plain spreading ridge, which migrated westward along the northern margins of the Naturaliste Plateau and Mentelle Basin between 132 to $124 \mathrm{Ma}$, and to proximity of the Kerguelen plume. A depositional hiatus or period of slow sedimentation occurred at Site U1513 on the Naturaliste Plateau between 121 to $110 \mathrm{Ma}$ as the plateau and central Mentelle Basin (Sites U1514 and U1516) subsided to middle bathyal depths. Periods of rapid deposition occurred in the Late Cretaceous (100 Ma) and again in Paleogene time (47 Ma), coinciding respectively with the onset of rifting between Australia and Antarctica and with breakup and establishment of normal seafloor spreading on the southern margin. High sedimentation rates in the Paleogene are likely due to increased carbonate productivity on the margin that resulted from establishment of a new ocean circulation pattern following separation of Antarctica from Australia.

\section{Acknowledgments}

We thank the crew and science staff of the JOIDES Resolution for a successful cruise. Postcruise core descriptions are facilitated by the IODP curators and staff at Gulf Coast and Kochi Core Center (Request No. 071241) repositories. Support for this research and the authors participation in IODP Expedition 369 were provided by the following agencies: United States Science Support Program Post-Expedition Research Award 70(GG009393) to DLH; Japan Drilling Earth Science Consortium to M.L.G.T.; K-IODP by the Ministry of Oceans and Fisheries and KRF program by the Ministry of Science and ICT through the NRF of Korea (2017H1D3A1A01054745) to E.Y.L.; Brian J. O'Neill Memorial Scholarship to E.W.; UK PostExpedition award (NE/R012261/1) to RWH; and financial support from the Australian and New Zealand IODP Consortium (ANZIC) who funded C.W., A.M., and L.T.W. We thank Nicholas Direen, John Hopper, and an anonymous reviewer for thoughtful and informative comments that greatly improved this manuscript.

\section{Open Research}

\section{Data Availability Statement}

Downhole geological, geophysical, and geochemical datasets used in this research are accessible through the following International Ocean Discover Program publications and their supplemental information files: Hobbs et al. (2019) and Huber et al. (2019a), available online at http://publications.iodp.org/proceedings/369/369title.html. Seismic reflection profiles shown in this paper are available from Geoscience Australia National Offshore Petroleum Information

This article is protected by copyright. All rights reserved. 
Management System (https://nopims.dmp.wa.gov.au/nopims). X-ray fluorescence spectrometry data for volcanic and volcaniclastic samples recovered at IODP Site U1513 are available at the PANGEA website (doi:https://doi.pangaea.de/10.1594/PANGAEA.924535).

\section{Figure Captions}

Figure 1. Naturaliste Plateau (NP), Perth Abyssal Plain (PAP), Mentelle Basin, and Perth Basin. Fracture zones and seafloor spreading isochrons (gray lines) from Borissova et al. (2002) and Gibbons et al. (2012), with isochron names modified to use more recent notation (Table 1). The Mentelle Basin is subdivided into an eastern part that overlies the central and western Yallingup Shelf, and a western part that includes the deep water basin and a portion overlying the eastern edge of the Naturaliste Plateau (Borissova et al., 2010). Ocean-continent transition (brown dashed line) after (Hall et al., 2013; Williams et al., 2011). Darling Fault (heavy black line) and other faults (thin gray lines) after (Borissova et al., 2010; Hall et al., 2013). Labelled red circles - Deep Sea Drilling Project (2xx) and International Ocean Discovery Program (U15xx) drilling sites; triangles - Bunbury Basalt outcrops; AFO - Albany-Fraser Orogen; LC = Leeuwin Complex; $\mathrm{NC}=$ Northampton Complex. Thin light gray lines show bathymetry (contour interval $=1000 \mathrm{~m}$ ). Thick red line indicates location of seismic profile S310-05 shown in Figure 3. Blue lines show locations of seismic profiles S310-03 (trending WSW) and S310-17 (trending NNW) shown in Figure 9.

Figure 2. Opening of the southeastern Indian Ocean. Plate reconstructions from GPlates based on the plate model of Gibbons et al. (2013) and geomagnetic time scale in Table 1. Extent of Greater India and location of Kerguelen plume from Gibbons et al. (2012). (a) Middle Permian - extension along the margins of the East Gondwana continents. (b) Late Jurassic renewed extension along the Permian rift trend. (c) late Valanginian - seafloor spreading begins between India and Antarctica and in the Perth Abyssal Plain between Greater India and Australia. Volcanism in the southern Perth Basin (130-137 Ma Bunbury Basalt; Olierook et al., 2016), near the ocean-continent transition in the northern Perth Basin, in the western Mentelle Basin and on the Naturaliste Plateau (128 to $132 \mathrm{Ma}$; Direen et al,, 2017), and on the conjugate Greater Indian margin (140-130 Ma Comei Basalts; Zhou et al., 2017). (d) early Barremian shortly after seafloor spreading begins between Greater India and the Naturaliste Plateau, coeval with volcanism on the Wallaby Plateau (124 Ma; Olierook et al., 2015). (e) Albian - a ridge jump transfers Gulden Draak and Batavia Knolls to the Australia-Antarctica plate. Volcanism was underway on the southern Kerguelen Plateau (118-119 Ma; Coffin et al., 2002; Duncan, 2002), on the conjugate Indian margin (Rajmahal Traps, 118 Ma; Ingle et al., 2004; Kent et al., 2002) and on Gulden Draak Knoll (117 Ma; Whittaker et al., 2016). (f) Albian - India begins to move northward after reorientation of the Southeast Indian Ridge. Extension between Australia and Antarctica and volcanism on the central Kerguelen Plateau and Broken Ridge begins. (g) Late Cretaceous - Mantle exhumation and/or slow seafloor spreading begins between Antarctica and Australia ca. $85 \mathrm{Ma}$. Continued Kerguelen hotspot volcanism begins to construct the Ninetyeast Ridge. (h) Paleogene - normal seafloor spreading begins between Australia and Antarctica.

Figure 3. Portions of seismic reflection profile S310-05 showing structural and stratigraphic characteristics of the southwestern Australian continental margin. Seismic sections align at edges as indicated by dotted lines to form a single profile, with $60 \mathrm{~km}$ gap between (a)

This article is protected by copyright. All rights reserved. 
and (b) and $7 \mathrm{~km}$ overlap between (b) and (c). (a) Portion of the eastern part of the profile crossing Yallingup Shelf and eastern Mentelle Basin showing location of IODP Site U1515. Solid vertical line shows Hole U1515A, with colored bars indicating boundaries between lithostratigraphic units discussed in text (roman numerals). (b) Portion of the central part of the seismic profile, crossing deep water western Mentelle Basin. (c) Portion of the western part of the seismic profile, crossing western edge of Mentelle Basin and eastern flank of the Naturaliste Plateau. Locations of IODP Site U1513 and DSDP Site 258 (not distinguishable from Site U1513 on this projection) are projected along structural strike from $20 \mathrm{~km}$ to the south. WD = water depth in meters; other numbers indicate depth below seafloor. Locations shown in Figure 1. Seismic profile is available from Geoscience Australia National Offshore Petroleum Information Management System (https://nopims.dmp.wa.gov.au/nopims). Seismic interpretation is modified after Hall et al. (2013), updated with IODP Expedition 369 drilling results using the time-depth conversions published in the Expedition 369 Proceedings for Sites U1513 (Huber et al., 2019a) and U1515 (Huber et al., 2019b).

Figure 4. Stratigraphic columns for IODP boreholes in the Mentelle Basin. Boreholes are arranged from west to east (white indicates no recovery). Compiled from Hobbs et al. (2019).

Figure 5. Major element binary plots and trace element ratio plots for volcanic rocks and dikes recovered from volcanic unit VI at IODP Site U1513 (data from Huber et al., 2019). Shown for comparison are data for dredged basaltic rocks from the Naturaliste Plateau (Coleman et al., 1982; Direen et al., 2017; Ford, 1975; Mahoney et al., 1995; Storey et al., 1992), Bunbury Basalt (Direen et al., 2017; Frey et al., 1996; Olierook et al., 2016), and Kerguelen Plateau basalts (Doucet et al., 2005; Frey et al., 2000; Kurnosov et al., 2003; Wallace et al., 2002; Weis and Frey, 2002). (a) total alkali vs. silica, showing basaltic composition of Site U1513 mafic rocks (classification diagram after Le Bas et al., 1986). (b) Representative trace element composition, showing Site U1513 and Kerguelen Plateau basalts to lie along a mixing trend between the Southeast Indian Ridge and Kerguelen plume basalts. (c) Major element composition, showing overlap with Kerguelen Plume, Southeast Indian Ridge, and Kerguelen Plateau basalts. High-MgO basalts are used for petrogenetic modeling as described in the text.

Figure 6. Modeled potential temperature $\left(T_{p}\right)$ vs. melting temperature, melting pressure, and degree of melting for mid-ocean ridge basalts, ocean island basalts, and oceanic plateau basalts and picrites obtained from the OBS1 petrogenetic model (adapted from Kimura and Kawabata, 2015). Symbols show OBS1 models for locations indicated in the legend. The green box shows modeling results for IODP Site U1513 basalts (this study). (a) Modeled melting temperature at the termination of melting $\left(\mathrm{T}_{\mathrm{mt}}\right)$ as a function of mantle potential temperature $\left(\mathrm{T}_{\mathrm{p}}\right)$. Gray circles and vertical bars indicate corresponding mantle solidus temperature $\left(\mathrm{T}_{\mathrm{m}}\right)$ at the mean melting pressure estimated from the OBS1 models. Horizontal and vertical red lines labelled PM2 indicate $T_{p}$ and $T_{m}$ at the olivine liquidus estimated using PRIMELTS2 (Herzberg and Asimow, 2008; Herzberg et al., 2007) for the indicated eruptive centers. Shaded areas indicate nominal ranges. Thick red curved line indicates $T_{m}-T_{p}$ correlation curve, with thin red lines indicating range. (b) Modeled mean melting pressure as a function of $T_{p}$. Shaded bars illustrate correlations within tectonic settings. (c) Mean melt fraction as a function of $\mathrm{T}_{\mathrm{p}}$.

This article is protected by copyright. All rights reserved. 
Symbols with red outlines indicate melt mixing trends as discussed by Kimura and Kawabata (2015).

Figure 7. Ages of strata recovered in IODP boreholes in the Mentelle Basin as a function of depth below seafloor. Green lines indicate ages of key tectonic events. Shaded areas represent intervals of rapid sedimentation with numbers indicating sedimentation rates $\left(\mathrm{m} \mathrm{Myr}^{-1}\right)$. Site U1515 is not shown due to poor age resolution. Curve at top shows global sea level (SL) relative to the modern datum (Haq et al., 1987). SFS = onset of seafloor spreading.

Figure 8. Evolution of the southwest Australian rifted margin. Left column - view of upper crust based on seismic profile S310-05 (Figure 3). Right column - schematic view of entire crust based primarily on gravity studies summarized in text. The profile crosses westward from the eastern edge of the southern Perth Basin across the Yallingup Shelf, Mentelle Basin, and Naturaliste Plateau. Extension direction is northwest (to left and into page) in c and d, and southward (out of page) in e and f. (a) Middle Jurassic (pre-rift). Late Permian through Early Jurassic post-rift strata cover syn-rift strata filling older Middle and Early Permian rift basins. (b) Late Jurassic (early syn-rift). Onset of rifting between Greater India and Australia, accompanied by formation of fault-bounded rift basins, uplift, and erosion west of the Darling Fault. (c) late Valanginian (Perth Abyssal Plain breakup). Onset of seafloor spreading on the Perth Abyssal Plain (north of profile), accompanied by basaltic volcanism in the southern Perth Basin and on the Naturaliste Plateau and in the western Mentelle Basin, where extension continues. Flows and sills in rift basin below the unconformity (red) are hypothetical. (d) early Barremian (Naturaliste Plateau breakup). Greater India and Australia separate and seafloor spreading west of the Naturaliste Plateau begins. Last volcanic eruptions on the Naturaliste Plateau occur immediately after breakup, followed by weathering and redistribution of basaltic material near sea level. (e) Late Cretaceous (immediately prior to breakup between Australia and Antarctica). Most of the margin subsided to mid-bathyal or greater depths prior to rapid subsidence immediately before the onset of normal seafloor spreading on the southern margin. (f) Rapid post-rift subsidence of the central Mentelle Basin followed the onset of seafloor spreading between Australia and Antarctica during the Neogene, producing the modern bathymetry. $\mathrm{CMB}=$ crust-mantle boundary.

Figure 9. Seismic reflection profiles showing high amplitude reflectors interpreted to be basalt flows. (a) Profile S310-17 trending WSW across the Mentelle Basin, showing probable volcanic/intrusive complex and associated flows that lies along strike of the Perth Basin/Perth Abyssal Plain ocean-continent transition further north. (b) Profile S310-03 trending NNW, showing reflectors that dip toward the ocean-continent boundary at the south edge of the Perth Abyssal Plain. Vertical dashed red line marks intersection of the two profiles. Profile locations shown in Figure 1. Seismic profiles available from Geoscience Australia National Offshore Petroleum Information Management System (https://nopims.dmp.wa.gov.au/nopims).

\section{Table Captions}

Table 1. Cretaceous Geomagnetic Time Scales and Ages of Seafloor Spreading Anomalies.

Table 2. Revised Hauterivian and lower Barremian Chron Ages.

Table 3. Petrogenetic Modeling Input Parameters and Results.

This article is protected by copyright. All rights reserved. 


\section{References}

Aguirre-Urreta, B., Martinez, M., Schmitz, M., Lescano, M., Omarini, J., Tunik, M., Kuhnert, H., Concheyro, A., Rawson, P.F., Ramos, V.A., Reboulet, S., Noclin, N., Frederichs, T., Nickl, A.-L., Pälike, H. (2019), Interhemispheric radio-astrochronological calibration of the time scales from the Andean and the Tethyan areas in the Valanginian-Hauterivian (Early Cretaceous). Gondwana Research, 70, 104-132, doi:10.1016/j.gr.2019.01.006

Ali, J.R., Aitchison, J.C. (2014), Greater India's northern margin prior to its collision with Asia. Basin Research, 26, 73-84. doi:10.1111/bre.12040

Ariskin A. A. (1999). Phase equilibria modeling in igneous petrology: use of COMAGMAT model for simulating fractionation of ferro-basaltic magmas and the genesis of high-alumina basalt. Journal of Volcanology and Geothermal Researches, 90, 115-162. doi:10.1016/S03770273(99)00022-0

Baksi, A. K. (1995), Petrogenesis and timing of volcanism in the Rajmahal flood basalt province, northeastern India. Chemical Geology, 121, 73-90. doi:10.1016/0009-2541(94)00124-Q

Baksi, A. K., Barman, T. R., Paul, D., Farrar, E. (1987), Widespread Early Cretaceous flood basalt volcanism in eastern India: geochemical data from the Rajmahal-Bengal-Sylhet traps. Chemical Geology, 63, 133-141. doi:10.1016/0009-2541(87)90080-5

Ball, P., Eagles, G., Ebinger, C., McClay, K., Totterdell, J. M. (2013), The spatial and temporal evolution of strain during the separation of Australia and Antarctica. Geochemistry, Geophysics, Geosystems, 14, 2771-2799. doi:10.1002/ggge.20160

Besse, J., Courtillot, V. (1988), Paleogeographic maps of the continents bordering the Indian ocean since the early Jurassic. Journal of Geophysical Research, 93, 11791-11808. doi:10.1029/JB093iB10p11791

Bodin, S., Godet, A., Föllmi, K. B., Vermeulen, J., Arnaud, H., Strasser, A., Fiet, N., Adatte, T. (2006), The late Hauterivian Faraoni oceanic anoxic event in the western Tethys: Evidence from phosphorus burial rates, Palaeogeography, Palaeoclimatology, Palaeoecology, 235, 245-264. doi:10.1016/j.palaeo.2005.09.030

Borissova, I. (2002), Geological framework of the Naturaliste Plateau, Geoscience Australia Record 2002/20, 44 pp., Geoscience Australia, Canberra.

Borissova, I., Bradshaw, B. E., Nicholson, C. J., Struckmeyer, H. I. M., Payne, D. (2010), New exploration opportunities on the southwest Australian margin - deep-water frontier Mentelle Basin. The APPEA Journal, 50, 47-58. doi:10.1071/AJ09004

Bradshaw, B. E., Rollet, N., Totterdell, J. M., Borissova, I. (2003), A revised structural framework for frontier basins on the southern and southwestern Australian continental margin, Geoscience Australia Record 2003/03, 43 pp., Geoscience Australia, Canberra.

Campbell, I. H., Griffiths, R. W. (1990), Implications of mantle plume structure for the evolution of flood basalts. Earth and Planetary Science Letters, 99, 79-93. doi:10.1016/0012$821 \mathrm{X}(90) 90072-6$

Cande, S. C., Mutter, J.C. (1982), A revised identification of the oldest sea-floor spreading anomalies between Australia and Antarctica. Earth and Planetary Science Letters, 58, 151-160. doi:10.1016/0012-821X(82)90190-X

This article is protected by copyright. All rights reserved. 
Castagna, J. P., Batzle, M. L., Eastwood, R. L. (1985), Relationships between compressionalwave and shear-wave velocities in clastic silicate rocks, Geophysics, 50(4), 571-581. doi: $10.1190 / 1.1441933$

Cawood, P. S., Korsch, R. J. (2008), Assembling Australia: Proterozoic building of a continent. Precambrian Research, 166, 1-38. doi:10.1016/j.precamres.2008.08.006

Christensen, N. L., Stanley, D. (2003), Seismic velocities and densities of rocks, in International Handbook of Earthquake and Engineering Seismology, Volume 81B, edited by W. Lee, H. Kanamori, P. Jennings, C. Kisslinger, pp. 1587-1594, Elsevier, Amsterdam. doi:10.1016/S00746142(03)80278-4

Coffin, M. F., Pringle, M. S., Duncan, R. A., Gladzenko, T. P., Storey, M., Müller, R. D., Gahagan, L. A. (2002), Kerguelen hotspot magma output since 130 Ma. Journal of Petrology, 43, 1121-1139. doi:10.1093/petrology/43.7.1121

Coleman, P. J., Michael, P. J., Mutter, J. C. (1982), The origin of the Naturaliste Plateau, SE Indian Ocean: Implications from dredged basalts. Journal of the Geological Society of Australia, 29, 457-468. doi:10.1080/00167618208729228

Colwell, J. B., Symonds, P. A., Crawford, A. J. (1994), The nature of the Wallaby (Cuvier) Plateau and other igneous provinces of the west Australian margin. AGSO Journal of Australian Geology and Geophysics, 15, 137-156

Crostella, A., and J. Backhouse (2000), Geology and petroleum exploration of the central and southern Perth Basin, western Australia, Report 57, 85 pp., Geological Survey of Western Australia, Perth.

Davies, T. A., Luyendyk, B. P., Rodolfo, K. S., Kempe, D. R. C., McKelvey, B. C., Leidy, R. D., Horvath, G. J., Hyndman, R. D., Thierstein, H. R., Herb, R. C., Boltovskoy, E., Doyle, P. (1974), Site 258. Deep Sea Drilling Project Initial Reports, 26, 359-414.

doi:10.2973/dsdp.proc.26.111.1974

Dentith, M. C., Dent, V. F., Drummond, B. J. (2000), Deep crustal structure in the southwestern Yilgarn Craton, Western Australia, Tectonophysics, 325, 227-255. doi:10.1016/S00401951(00)00119-0

Direen, N. G., I. Borissova, H. M. J. Stagg, J. B. Colwell, and P. A. Symonds (2007), Nature of the ocean-continent transition along the southern Australian continental margin: a comparison of the Naturaliste Plateau, SW Australia, and the central Great Australian Bight sectors, in Imaging, Mapping, and Modeling Continental Lithosphere Extension and Breakup, Special Publication 282, edited by G. D. Karner, G. Manatschal and L. M. Punheiro, pp. 239-263, Geological Society of London, London. doi:10.1144/SP282.12

Direen, N. G., B. E. Cohen, R. Maas, F. A. Frey, J. M. Whittaker, M. F. Coffin, S. Meffre, J. A. Halpin, and A. J. Crawford (2017), Naturaliste Plateau: constraints on the timing and evolution of the Kerguelen Large Igneous province and its role in Gondwana breakup, Australian Journal of Earth Sciences, 64(7), 851-869. doi:10.1080/08120099.2017.1367326

Direen, N. G., Stagg, H. M. J., Symonds, P. A., Colwell, J. B. (2008), Architecture of volcanic rifted margins: new insights from the Exmouth-Gascoyne margin, Western Australia, Australian Journal of Earth Sciences, 55, 341-363. doi:10.1080/08120090701769472

This article is protected by copyright. All rights reserved. 
Direen, N. G., Stagg, H. M. J., Symonds, P. A., Colwell, J. B. (2011), Dominant symmetry of a conjugate southern Australian and East Antarctic magma-poor rifted margin segment. Geochemistry, Geophysics, Geosystems, 12. doi:10.1029/2010GC003306

Dosso, L., Bougault, H., Beuzart, P., Calvez, J.-Y., and Joron, J.-L. (1988), The geochemical structure of the South-East Indian Ridge. Earth and Planetary Science Letters, 88, 47-59. doi:10.1016/0012-821X(88)90045-3

Doucet, S., Scoates, J. S., Weis, D., and Giret, A. (2005), Constraining the components of the Kerguelen mantle plume: A Hf-Pb-Sr-Nd isotopic study of picrites and high-MgO basalts from the Kerguelen Archipelago. Geochemistry, Geophysics, Geosystems, 6(4), Q04007. doi:10.1029/2004GC000806

Duncan, R. A. (2002), A time frame for construction of the Kerguelen Plateau and Broken Ridge. Journal of Petrology, 43, 1109-1119. doi:10.1093/petrology/43.7.1109

Falvey, D. A. (1974), The development of continental margins in plate tectonic theory, The APPEA Journal, 14(1), 95-106. doi:10.1071/AJ73012

Fisher, R.V. (1961), Proposed classification of volcaniclastic sediments and rocks. Geological Society of America Bulletin, 72, 1409-1414. doi:10.1130/00167606(1961)72[1409:PCOVSA]2.0.CO;2

Ford, A. B. (1975), Volcanic rocks of Naturaliste Plateau, eastern Indian Ocean, Site 264, DSDP leg 28. Initial Reports of the Deep Sea Drilling Project, 28, 821-833.

Frau, C., Bulot, L.G., Delanoy, G., Moreno-Bedmar, J.A., Masse, J.-P., Tendil, A., J.-B., Lanteaume, C. (2018), The Aptian GSSP candidate at Gorgo a Cerbara (Central Italy): an alternative interpretation of the bio-, litho- and chemostratigraphic markers. Newsletters on Stratigraphy, 51, 311-326. doi:10.1127/nos/2017/0422

Frey, F. A., McNaughton, N. J., Nelson, D. R., Duncan, R. A. (1996), Petrogenesis of the Bunbury Basalt, Western Australia: interaction between the Kerguelen plume and Gondwana lithosphere? Earth and Planetary Science Letters, 144, 163-183. doi:10.1016/0012821X(96)00150-1

Frey, F. A., Coffin, M. F., Wallace, P. J., Weis, D., Zhao, X., Wise, S.W., Jr., Wähnert, V., Teagle, D. A., Saccocia, P. J., Reusch, D. N., Pringle, M. S. (2000), Origin and evolution of a submarine large igneous province: the Kerguelen Plateau and Broken Ridge, southern Indian Ocean. Earth and Planetary Science Letters, 176, 73-89, doi:10.1016/S0012-821X(99)00315-5

Fullerton, L. G., Sager, W. W., Handschumacher, D. W. (1989), Late Jurassic-Early Cretaceous evolution of the eastern Indian Ocean adjacent to northwest Australia. Journal of Geophysical Research, 94, 2937-2953. doi:10.1029/JB094iB03p02937

Gaina, C., Müller, R. D., Brown, B., Ishihara, T., Ivanov, S. (2007), Breakup and early seafloor spreading between India and Antarctica. Geophysical Journal International, 170, 151-169. doi:10.1111/j.1365-246X.2007.03450.x

Gee, J. S., Kent, D. V. (2007), Source of oceanic magnetic anomalies and the Geomagnetic Time Scale. Treatise on Geophysics, 5. 455-507. doi:10.1016/B978-044452748-6.00097-3

Gibbons, A .D., Barckhausen, U., van den Bogaard, P., Hoernle, K., Werner, R., Whittaker, J. M., Müller, R. D. (2012), Constraining the Jurassic extent of Greater India: Tectonic evolution of

This article is protected by copyright. All rights reserved. 
the West Australian margin. Geochemistry, Geophysics, Geosystems, 13, Q05W13. doi:10.1029/2011GC003919

Gibbons, A. D., Whittaker, J. M., Müller, R. D. (2013), The breakup of East Gondwana: Assimilating constraints from Cretaceous ocean basins around India into a best-fit tectonic model. Journal of Geophysical Research, 118, 808-822. doi:10.1002/jgrb.50079

Goncharov, A., Nelson, G. (2012), From two way time to depth and pressure for interpretation of seismic velocities offshore: Methodology and examples from the Wallaby Plateau on the West Australian margin. Tectonophysics, 572-573, 26-37. doi: 10.1016/j.tecto.2012.06.037

Gradstein, F. M., Ogg, J. G., Schmitz, B., Ogg, G. (2012), The Geologic Time Scale 2012. 1144 pp., Elsevier, Amsterdam.

Gudfinnsson, G. H., Presnall, D. C. (2005), Continuous gradations among primary carbonatitic, kimberlitic, melilititic, basaltic, picritic, and komatiitic melts in equilibrium with garnet lherzolite at 3-8GPa. Journal of Petrology, 46, 1645-1659. doi:10.1093/petrology/egi029

Hall, L. S., Gibbons, A. D., Bernardel, G., Whittaker, J., Nicholson, C., Rollet, N., Müller, R. D. (2013), Structural Architecture of Australia's Southwest Continental Margin and Implications for Early Cretaceous Basin Evolution, in S. J. Moss, M. Keep, M. (Eds.), p. 2-20, West Australian Basins Symposium, Petroleum Exploration Society of Australia, Perth.

Halpin, J. A., Crawford, A. J., Direen, N. G., Coffin, M. F., Forbes, C.J., Borissova, I. (2008), Naturaliste Plateau, offshore Western Australia: A submarine window into Gondwana assembly and breakup. Geology, 36, 807-810. doi:10.1130/G25059A.1

Halpin, J. A., Daczko, N. R., Direen, N. G., Mulder, R. C., Ishihara, T. (2020), Provenance of rifted continental crust at the nexus of East Gondwana breakup. Lithos, 354-355, 105363. doi:10.1016/j.lithos.2019.105363

Harris, L.B. (1994), Structural and tectonic synthesis for the Perth Basin, western Australia. Journal of Petroleum Geology, 17, 129-156. doi:10.1111/j.1747-5457.1994.tb00123.x

Harrowfield, M., Holdgate, G. R., Wilson, C. J. L., McLoughlin, S. (2005), Tectonic significance of the Lambert graben, East Antarctica: Reconstructing the Gondwanan rift. Geology, 33, 197200. doi:10.1130/G21081.1

Haq, B. U., Hardenbol, J., Vail, P. R. (1987), Chronology of fluctuating sea levels since the Triassic. Science, 235, 1156-1167. doi:10.1126/science.235.4793.1156

Haq, B. U. (2014), Cretaceous eustacy revisted, Global and Planetary Change, 113, 44-58, doi:10.1016/j.gloplacha.2013.12.007

Heine, C., Müller, R. (2005), Late Jurassic rifting along the Australian North West Shelf: margin geometry and spreading ridge configuration. Australian Journal of Earth Sciences, 52, 27-39. doi:10.1080/08120090500100077

Herzberg, C., Asimow, P. D., Arndt, N., Niu, Y., Lesher, C. M., Fitton, J. G., Cheadle, M. J., Saunders, A. D. (2007), Temperatures in ambient mantle and plumes: Constraints from basalts, picrites, and komatiites. Geochemistry, Geophysics, Geosystems, 8, Q02006.

doi:10.1029/2006GC001390

This article is protected by copyright. All rights reserved. 
Hobbs, R. W., Huber, B. T., Bogus, K. A., Batenburg, S. J., Brumsack, H.-J., do Monte Guerra, R., Edgar, K. M., Edvardsen, T., Garcia Tejada, M. L., Harry, D. L., Hasegawa, T., Haynes, S. J., Jiang, T., Jones, M. M., Kuroda, J., Lee, E. Y., Li, Y.-X., MacLeod, K. G., Maritati, A., Martinez, M., O’Connor, L. K., Petrizzo, M. R., Quan, T. M., Richter, C., Riquier, L., Tagliaro, G. T., Wainman, C. C., Watkins, D. K., White, L. T., Wolfgring, E., Xu, Z. (2019), Expedition 369: Australia Cretaceous Climate and Tectonics. Proceedings of the International Ocean Discovery Program, 369, International Ocean Discovery Program, College Station, TX

Huber, B. T., Hobbs, R. W., Bogus, K. A., Batenburg, S. J., Brumsack, H.-J., do Monte Guerra, R., Edgar, K. M., Edvardsen, T., Garcia Tejada, M. L., Harry, D. L., Hasegawa, T., Haynes, S .J., Jiang, T., Jones, M. M., Kuroda, J., Lee, E. Y., Li, Y.-X., MacLeod, K. G., Maritati, A., Martinez, M., O’Connor, L. K., Petrizzo, M. R., Quan, T. M., Richter, C., Riquier, L., Tagliaro, G. T., Wainman, C. C., Watkins, D. K., White, L. T., Wolfgring, E., Xu, Z. (2018), Expedition 369 Preliminary Report: Australia Cretaceous Climate and Tectonics, 39 pp., International Ocean Discovery Program, College Station, TX

Huber, B. T., Hobbs, R. W., Bogus, K. A., Batenburg, S. J., Brumsack, H.-J., do Monte Guerra, R., Edgar, K. M., Edvardsen, T., Garcia Tejada, M. L., Harry, D. L., Hasegawa, T., Haynes, S. J., Jiang, T., Jones, M. M., Kuroda, J., Lee, E. Y., Li, Y.-X., MacLeod, K. G., Maritati, A., Martinez, M., O’Connor, L. K., Petrizzo, M. R., Quan, T. M., Richter, C., Riquier, L., Tagliaro, G. T., Wainman, C. C., Watkins, D. K., White, L. T., Wolfgring, E., Xu, Z. (2019a), Site U1513. in R. W. Hobbs, B. T. Huber, K. A. Bogus, K. A., and the Expedition 369 Scientists, Australia Cretaceous Climate and Tectonics. Proceedings of the International Ocean Discovery Program, 369, International Ocean Discovery Program, College Station, TX. doi:10.14379/iodp.proc.369.104.2019

Huber, B. T., Hobbs, R. W., Bogus, K. A., Batenburg, S. J., Brumsack, H.-J., do Monte Guerra, R., Edgar, K. M., Edvardsen, T., Garcia Tejada, M. L., Harry, D. L., Hasegawa, T., Haynes, S. J., Jiang, T., Jones, M. M., Kuroda, J., Lee, E. Y., Li, Y.-X., MacLeod, K. G., Maritati, A., Martinez, M., O’Connor, L. K., Petrizzo, M. R., Quan, T. M., Richter, C., Riquier, L., Tagliaro, G. T., Wainman, C. C., Watkins, D. K., White, L. T., Wolfgring, E., Xu, Z. (2019b), Site U1515. in R. W. Hobbs, B. T. Huber, K. A. Bogus, K. A., and the Expedition 369 Scientists, Australia Cretaceous Climate and Tectonics. Proceedings of the International Ocean Discovery Program, 369, International Ocean Discovery Program, College Station, TX.

doi:10.14379/iodp.proc.369.106.2019

Ingle, S., Scoates, J., Weis, D., Brügmann, G., Kent, R. (2004), Origin of Cretaceous continental tholeiites in southwestern Australia and eastern India: insights from Hf and Os isotopes.

Chemical Geology, 209, 83-106. doi:10.1016/j.chemgeo.2004.04.023

Ingle, S., Weis, D., Scoates, J. S., Frey, F. A. (2002), Relationship between the early Kerguelen plume and continental flood basalts of the paleo-Eastern Gondwanan margins. Earth and Planetary Science Letters, 197, 35-50. doi:10.1016/S0012-821X(02)00473-9

Johnston, S., Hackney, R., Nicholson, C. (2010), Distribution of igneous facies and potentialfield modelling of the Mentelle Basin, southwestern margin, Australia. Australian Society of Exploration Geophysicists Extended Abstracts, 2010, 1-4. doi:10.1081/22020586.2010.12041965

Kennett, J. P., Burns, R. E., Andrews, J. E., Churkin, M., Davies, T. A., Dumitrica, P., Edwards, A. R., Galehouse, J. S., Packham, G. H., van der Lingen, G. J. (1972), Australian-Antarctic

This article is protected by copyright. All rights reserved. 
continental drift, paleocirculation changes and Oligocene deep-sea erosion: Nature Physical Science, 239, p. 51-55.

Kennett, B. L. N., Salmon, M., Saygin, E., AusMoho Working Group (2011), AusMoho: the variation of Moho depth in Australia, Geophysical Journal International, 187, 946-958. doi:10.1111/j.1365-246X.2011.05194.x

Kent, R. (1991), Lithospheric uplift in eastern Gondwana: evidence for a long-lived mantle plume system? Geology, 19, 19-23. doi:10.1130/0091-7613(1991)019<0019:LUIEGE>2.3.CO;2

Kent, R. W., Pringle, M. S., Müller, R. D., Saunders, A. D., Ghose, N. C. (2002), 40Ar/39Ar geochronology of the Rajmahal basalts, India, and their relationship to the Kerguelen Plateau. Journal of Petrology, 43, 1141-1153. doi: 10.1093/petrology/43.7.1141

Kimura, J.-I., Ariskin, A. A. (2014), Calculation of water-bearing primary basalt and estimation of source mantle conditions beneath arcs: PRIMACALC2 model for WINDOWS. Geochemistry Geophysics Geosystem, 15, 1494-1514. doi: 10.1002/2014GC005329

Kimura, J.-L., Kawabata, H. (2015), Ocean Basalt Simulator version 1 (OBS1): Trace element mass balance in adiabatic melting of a pyroxenite-bearing peridotite. Geochemistry, Geophysics, Geosystems, 16, 267-300. doi:10.1002/2014GC005606

Ksienzyk, A. K., Jacobs, J., Boger, S. D., Kosler, J., Sircombe, K. N., Whitehouse, M. J. (2012), $\mathrm{U}-\mathrm{Pb}$ ages of metamorphic monazite and detrital zircon from the Northampton Complex: evidence of two orogenic cycles in Western Australia. Precambrian Research, 198-199, 37-50. doi:10.1016/j.precamres.2011.12.011

Kurnosov, V., Zolotarev, B., Artamonov, A., Garanina, S., Petrova, V., Eroshchev-Shak, V., Sokolova, A. (2003), Data Report: Alteration of basalts from the Kerguelen Plateau, in F. A. Frey, M. F. Coffin, P. J. Wallace, P. G. Quilty (Eds.), Proceedings of the Ocean Drilling Program, Scientific Results, 183, 1-40, Ocean Drilling Program, College Station, TX

Lavier, L. L., Manatschal, G. (2006), A mechanism to thin the continental lithosphere at magmapoor margins. Nature, 440, 324-328. doi: 10.1038/nature04608Lawver, L. A., Gahagan, L. M., Coffin, M. F. (1992), The development of paleoseaways around Antarctica, in J. P. Kennett and D.A. Warkne, (Eds.), The Antarctic Paleoenvironment: Perspectives on Global Change: Part One. p. 7-30, American Geophysical Union, Washington, D. C.

Le Bas, M. J., Le Maitre, R., Streckeisen, A., and Zanettin, B. (1986), A chemical classification of volcanic rocks based on the total alkali-silica diagram. Journal of Petrology, 27, 745-750. doi:10.1093/petrology/27.3.745

Le Pichon, X., Barbier, F. (1987), Passive margin formation by low-angle faulting within the upper crust; the northern Bay of Biscay margin. Tectonics, 6, 133-150. doi:10.1029/TC006i002p00133

Lee, E. Y., Novotny, J., Wagreich, M. (2019), Subsidence Analysis and Visualization for sedimentary basin analysis and modelling. SpringerBriefs in Petroleum Geoscience \& Engineering. Springer, NY. doi:10.1007/978-3-319-76424-5

Lee, E. Y., Wolfgring, E., Tejada, M. L. G., Harry, D. L., Wainman, C. C., Chun, S. S., Schnetger, B., Brumsack, H.-J., Maritati, A., Richter, C., Lie, Y.-X., Riquier, L., MacLeod, K. G., Waller, T. R., Borissova, I., Martinez, M., Petrizzo, M. R., Humber, B. T., Kim, Y., Party, I.

This article is protected by copyright. All rights reserved. 
E. S. (2020), Early Cretaceous subsidence of the Naturaliste Plateau defined by a new record of volcaniclastic-rich sequence at IODP Site U1513. Gondwana Research, 82, 1-11. doi:10.1016/j.gr.2019.12.007

Liu, Z., Zhou, Q., Lai, Y., Qing, C., Li, Y., Wu, J., Xia, X. (2015), Petrogenesis of the Early Cretaceous Laguila bimodal intrusive rocks from the Tethyan Himalaya: Implications for the break-up of Eastern Gondwana. Lithos, 236-237, 190-202. doi:10.1016/j.lithos.2015.09.006

Luyendyk, B. P., Davies, T. A. (1974), Results of DSDP Leg 26 and the Geologic History of the Southern Indian Ocean, Deep Sea Drilling Project Initial Reports, 26, 909-943. doi:10.2973/dsdp.proc.26.136.1974

Mahoney, J. J., Jones, W. B., Frey, F. A., Salters, V. J. M., Pyle, D. G., and Davies, H. L. (1995), Geochemical characteristics of lavas from Broken Ridge, the Naturaliste Plateau and southernmost Kerguelen Plateau: Cretaceous plateau volcanism in the southeast Indian Ocean. Chemical Geology, 120, 315-345. doi:10.1016/0009-2541(94)00144-W

Malinverno, A., Hildebrandt, J., Tominaga, M., Channell, J. E. T. (2012), M-sequence geomagnetic polarity time scale (MHTC12) that steadies global spreading rates and incorporates astrochronology constraints. Journal of Geophysical Research, 117. doi:10.1029/2012JB009260

Maloney, D., Sargent, C., Direen, N.G., Hobbs, R. W., Grocke, D. R. (2011), Re-evaluation of the Mentelle Basin, a polyphase rifted margin basin, offshore southwest Australia: new insights from integrated regional seismic datasets. Solid Earth, 2, 107-123. doi:10.5194/se-2-107-2011

Manville, V., Nemeth, K., Kano, K. (2009), Source to sink: A review of three decades of progress in the understanding of volcaniclastic processes, deposits, and hazards, Sedimentary Geology, 220, 136-161. doi:10.1016/j.sedgeo.2009.04.022

Maritati, A., Danisik, M., Halpin, J. A., Whittaker, J. M., Aitken, A. R. A. (2020). Pangea rifting shaped the East Antarctic Landscape, Tectonics, 39, e2020TC006180. doi:10.1029/2020TC006180

Markl, R. G. (1974), Evidence for the breakup of eastern Gondwanaland by the Early Cretaceous. Nature, 251, 196-200. doi:10.1038/251196a0

Markl, R. G. (1978), Evidence for the early Cretaceous breakup of Gondwanaland off southwestern Australia. Marine Geology, 26, 41-48. doi:10.1016/0025-3227(78)90044-0

Martinez, M., Deconinck, J. F., Pellenard, P., Reboulet, S., Riquier, L. (2013), Astrochronology of the Valanginian Stage from reference sections (Vocontian Basin, France) and palaeoenvironmental implications for the Weissert Event. Palaeogeography, Palaeoclimatology, Palaeoecology, 376, 91-102, doi:10.1016/j.palaeo.2013.02.021.

Mathews, K. J., Seton, M., Muller, R. D. (2012), A global-scale plate reorganization event at 105-100 Ma. Earth and Planetary Science Letters, 355-356, 283-298. doi:10.1016/j.epsl.2012.08.023

Mathur, S. P. (1974), Crustal structure in southwestern Australia from seismic and gravity data, Tectonophysics, 24, 151-182. doi:10.1016/0040-1951(74)90135-8

McKenzie, D. (1978), Some remarks on the development of sedimentary basins, Earth and Planetary Science Letters, 40, 25-32. doi:10.1016/0012-821X(78)90071-7

This article is protected by copyright. All rights reserved. 
McKenzie, D., Bickle, M. J. (1988), The volume and composition of melt generated by extension of the lithosphere. Journal of Petrology, 29, 625-679. doi:10.1093/petrology/29.3.625

McKenzie, D., Jackson, J. A., Priestley, K. (2005), Thermal structure of oceanic and continental lithosphere. Earth and Planetary Science Letters, 233, 337-349. doi:10.1016/j.eps1.2005.02.005

McPhie, J., Doyle, M., Allen, R. (1993), Volcanic Textures; A guide to the interpretation of textures in volcanic rocks, 196 pp., Centre for Ore Deposit and Exploration Studies University of Tasmania, Hobart

Mihut, D., Müller, R. D. (1998), Volcanic margin formation and Mesozoic rift propagators in the Cuvier Abyssal Plain off western Australia. Journal of Geophysical Research, 103, 2713527149. doi:10.1029/97JB02672

Molnar, P. (2004), Late Cenozoic Increase in Accumulation rates of terrestrial sediment: How might climate change have affected erosion rates? Annual Review of Earth and Planetary Sciences, 32, 67-89. doi:10.1146/annurev.earth.32.091003.143456

Mulder, T. (2011), Gravity Processes and Deposits on Continental Slope, Rise and Abyssal Plains, Developments in Sedimentology, 63, 25-148. doi:10.1016/B978-0-444-53000-4.00002-0

Müller, R. D., C. Gaina, A. Tikku, D. Mihut, S. C. Cande, and J. M. Stock (2000), Mesozoic/Cenozoic tectonic events around Australia, in History and Dynamics of Global Plate Motions, Geophysical Monograph 121, edited by M. A. Richards, R. G. Gordon and R. D. Van Der Hilst, pp. 161-188, American Geophysical Union, Washington, DC.

Mutter, J. C., Hegarty, K. A., Cande, S. C., Weissel, J. K. (1985), Breakup between Australia and Antractica: A brief review in the light of new data. Tectonophysics, 114, 255-279. doi:10.1016/0040-1951(85)90016-2

Mutter, J. C., M. Talwani, and P. Stoffa (1982), Origin of seaward-dipping reflectors in oceanic crust off the Norwegian margin by subaerial seafloor spreading, Geology, 10, 353-357, doi:10.1130/0091-7613(1982)10<353:OOSRIO>2.0.CO;2

Norton, I. O., Sclater, J. G. (1979), A model for the evolution of the Indian Ocean and the breakup of Gondwanaland. Journal of Geophysical Research, 84, 6803-6830. doi:10.1029/JB084iB12p06803

Norvick, M. S. (2004), Tectonic and stratigraphic history of the Perth Basin, Geoscience Australia Record 2004/16, 30 pp., Geoscience Australia, Canberra

Ogg, J. G., Gabi, M., Gradstein, F. M. (2016), A concise geologic time scale, 240 pp., Elsevier, Amsterdam.

Olierook, H. K. H., Jiang, Q., Jourdan, F., Chiaradia, M. (2019), Greater Kerguelen large igneous province reveals no role for Kerguelen mantle plume in the continental breakup of eastern Gondwana. Earth and Planetary Science Letters, 511, 244-255. doi:10.1016/j.eps1.2019.01.037

Olierook, H.K.H, Jourdan, F., Merle, F. (2019). Age of the Barremian-Aptian boundary and onset of the Cretaceous Normal Superchron. Earth-Science Reviews, 197, doi:10.1016/j.earscirev.2019.102906

This article is protected by copyright. All rights reserved. 
Olierook, H. K. H., Jourdan, F., Merle, R. E., Timms, N. E., Kusznir, N., Muhling, J. R. (2016), Bunbury Basalt: Gondwana breakup products or earliest vestiges of the Kerguelen mantle plume? Earth and Planetary Science Letters, 440, 20-32. doi:10.1016/j.eps1.2016.02.008

Olierook, H. K. H., Merle, R..E., Jourdan, F. (2017), Toward a Greater Kerguelen large igneous province: Evolving mantle source contributions in and around the Indian Ocean. Lithos, 282-283, 163-172. doi:10.1016/j.lithos.2017.03.007

Olierook, H. K. H., Merle, R. E., Jourdan, F., Sircombe, K., Faser, G., Timms, N. E., Nelson, G., Dadd, K. A., Kellerson, L., Borissova, I. (2015), Age and geochemistry of magmatism on the oceanic Wallaby Plateau and implications for the opening of the Indian Ocean. Geology, 43, 971-974. doi:10.1130/G37044.1

Owens, R. J., Borissova, I., Hall, L. S., Bernardel, G., Southby, C., Grosjean, E. and Mitchell, C. (2018), Extensional during rifting direction Geology and prospectivity of the northern Houtman Sub basin. Geoscience Australia Record 2018/25, Geoscience Australia, Canberra

Plumb, K. A. (1979), The tectonic evolution of Australia. Earth Science Reviews, 14, 205-249. doi:10.1016/0012-8252(79)90001-1

Powell, C. M., Roots, S. R., Veevers, J. J. (1988), Pre-breakup continental extension in East Gondwanaland and the early opening of the eastern Indian Ocean. Tectonophysics, 155, 261-283. doi:10.1016/0040-1951(88)90269-7

Powell, T. S., Luyendyk, B. P. (1982), The sea-floor spreading history of the eastern Indian ocean. Marine Geophysical Researches, 5, 225-247. doi:10.1007/BF00305562

Presnall, D. C., Gudfinnsson, G. H., Walter, M. J. (2002), Generation of mid $\square$ ocean ridge basalts at pressures from 1 to $7 \mathrm{GPa}$. Geochemica et Cosmochimica Acta, 66, 2073-2090. doi:10.1016/S0016-7037(02)00890-6

Putirka, K. (2005), Mantle potential temperatures at Hawaii, Iceland, and the mid $\square$ ocean ridge system, as inferred from olivine phenocrysts: Evidence for thermally driven mantle plumes. Geochemistry, Geophysics, Geosystems, 6, Q05L08. doi:10.1029/2005GC000915

Reading, A. M., Kennett, B. L. N., Dentith, M. C. (2003), Seismic structure of the Yilgarn Craton, Western Australia, Australian Journal of Earth Sciences, 50(3), 427-438. doi:10.1046/j.1440-0952.2003.01000.x

Reston, T. J., Pennell, J., Stubenrauch, A., Wlaker, I., Perez-Gussinye, M. (2001), Detachment faulting, mantle serpentinization, and serpentinite-mud volcanism beneath the Porcupine Basin, southwest of Ireland. Geology, 29, 587-590. doi:10.1130/0091-

7613(2001)029<0587:DFMSAS>2.0.CO;2

Robb, M. S., Taylor, B., Goodliffe, A. M. (2005), Re-examination of the magnetic lineations of the Gascoyne and Cuvier Abyssal Plains, off NW Australia. Geophysical Journal International, 163, 42-55. doi:10.1111/j.1365-246X.2005.02727.x

Royer, J.-Y., Coffin, M. F. (1992), Jurassic to Eocene plate tectonic reconstructions in the Kerguelen Plateau region. In: Wise, S. W., Jr., Schlich, R. (Eds.), Proceedings of the Ocean Drilling Program, Scientific Results, 129, 917-928, Ocean Drilling Program, College Station, TX

This article is protected by copyright. All rights reserved. 
Royer, J.-Y., Sandwell, D. T. (1989), Evolution of the eastern Indian ocean since the Late Cretaceous: constraints from GEOSAT altimetry. Journal of Geophysical Research, 94, 13,755713,783. doi:10.1029/JB094iB10p13755

Saygin, E., Kennett, B. L. N. (2012), Crustal structure of Australia from ambient seismic noise tomography, Journal of Geophysical Research, 117, B01304, doi:10.1029/2011JB008403

Sayers, J., Symonds, P. A., Direen, N. G., Bernadel, G. (2001), Nature of the continent-ocean transition on the non-volcanic rifted margin of the central Great Australian Bight, in Nonvolcanic Rifting of Continental Margins: A Comparison of Evidence from Land and Sea, R. C. L. Wilson, R. B.Whitmarsh, B. Taylor and N. Froitzheim (Eds.), Geological Society of London Special Publication 187, 51-76, Geological Society of London, London. doi.org/10.1144/GSL.SP.2001.187.01.04

Sclater, J. G., Fisher, R. L. (1974), Evolution of the East Central Indian Ocean, with emphasis on the tectonic setting of the Ninetyeast Ridge. Geological Society of America Bulletin, 85, 683702. doi:10.1130/0016-7606(1974)85<683:EOTECI>2.0.CO;2

Sircombe, K. N., Freeman, M. J. (1999), Provenance of detrital zircons on the Western Australia coastline-Implications for the geologic history of the Perth basin and denudation of the Yilgarn craton. Geology, 27, 879-882. doi:10.1130/0091-7613(1999)027<0879:PODZOT>2.3.CO;2

Song, T., Cawood, P. S. (2000), Structural styles in the Perth Basin associated with the Mesozoic break-up of Greater India and Australia. Tectonophysics, 317, 55-72. doi:10.1016/S00401951(99)00273-5

Steckler, M. S., Watts, A. B. (1978), Subsidence of the Atlantic-type continental margin off New York. Earth and Planetary Science Letters, 41, 1-13. doi:10.1016/0012-821X(78)90036-5

Storey, M., Saunders, A .D., Tarney, J., Gibson, I. L., Norry, M. J., Thirlwall, M. F., Leat, P., Thompson, R. N., Menzies, M. A. (1989), Contamination of Indian Ocean asthenosphere by the Kerguelen-Heard mantle plume. Nature, 338, 574-576. doi:10.1038/338574a0

Symonds, P. A., Planke, S., Frey, O., Skogseid, J. (1998), Volcanic evolution of the Western Australian continental margin and its implications for basin development, in P. G. Purcell, and R. R. Purcell (Eds.), The Sedimentary Basins of Western Australia 2, p. 33-54, Petroleum Exploration Society of Australia, Perth

Tejada, M. L. G., Lee, E. Y., Chun, S. S., Harry, D. L., Riquier, L. Wainman, C. C. (2020), Data report: petrology and volcanic stratigraphy at Site U1513, IODP Expedition 369, in R.W. Hobbs, B.T. Huber, K. A. Bogus, and the Expedition 369 Scientists, Australia Cretaceous Climate and Tectonics. Proceedings of the International Ocean Discovery Program, 369: College Station, TX (International Ocean Discovery Program). doi:10.14379/iodp.proc.369.202.2020

Tikku, A. A., Cande, S. C. (1999), The oldest magnetic anomalies in the Australian-Antarctic Basin: Are they isochrons? Journal of Geophysical Research, 104, 661-677. doi:10.1029/1998JB900034

Tikku, A. A., Direen, N. G. (2008), Comment on "Major Australian-Antarctic Plate Reorganization at Hawaiian-Emperor Bend Time". Science, 321, 490. doi:10.1126/science. 1157163

This article is protected by copyright. All rights reserved. 
Veevers, J. J. (1986), Breakup of Australia and Antarctica estimated as Mid-Cretaceous (95+5 Ma) from magnetic and seismic data at the continental margin. Earth and Planetary Science Letters, 77, 91-99. doi:10.1016/0012-821X(86)90135-4

Veevers, J. J. (2006), Updated Gondwana (Permian-Cretaceous) earth history of Australia. Gondwana Research, 9, 231-260. doi:10.1016/j.gr.2005.11.005

Wainman, C. C., I. Borissova, D. L. Harry, R. W. Hobbs, D. J. Mantle, A. Maritati, E. Y. Lee, and Expedition 369 Science Party (2020), Evidence for non-marine Jurassic to earliest Cretaceous sediments in the pre-breakup section of the Mentelle Basin. Australian Journal of Earth Sciences, 67, 89-105. doi:10.1080/08120099.2019.1627581

Wallace, P. J. (2002), Volatiles in submarine basaltic glasses from the Northern Kerguelen Plateau (ODP Site 1140): implications for source region compositions, shallow magmatic processes and plateau subsidence. Journal of Petrology. 43, 1311-1326. doi:10.1093/petrology/43.7.1311

Wallace, P. J., Frey, F. A., Weis, D., Coffin, M. F., (2002), Origin and evolution of the Kerguelen Plateau, Broken Ridge and Kerguelen archipelago: Editorial, Journal of Petrology, 43(7), 1105-1108. doi:10.1093/petrology/43.7.1105

Watson, S. J., Whittaker, J. M., Halpin, J. A., Williams, S. E., Milan, L. A., Daczko, N. R., Wyman, D. A. (2016), Tectonic drivers and the influence of the Kerguelen plume on seafloor spreading during formation of the early Indian Ocean. Gondwana Research, 35, 97-114. doi:10.1016/j.gr.2016.03.009

Weis, D., Frey, F. A. (2002), Submarine basalts of the Northern Kerguelen Plateau: interaction between the Kerguelen Plume and the Southeast Indian Ridge revealed at ODP Site 1140. Journal of Petrology, 43, 1287-1310. doi:10.1093/petrology/43.7.1287

White, L. T., Gibson, G. M., Lister, G. S. (2013), A reassessment of paleogeographic reconstructions of eastern Gondwana: Bringing geology back into the equation. Gondwana Research, 24, 984998. doi:10.1016/j.gr.2013.06.009

White, R. S., McKenzie, D. (1995), Mantle plumes and flood basalts. Journal of Geophysical Research, 100, 17543-17585. doi:10.1029/95JB01585

Whitechurch, H., Montigny, R., Sevigny, J., Storey, M., Salters, V. (1992), K-Ar and 40Ar-39Ar ages of central Kerguelen Plateau basalts, Proceedings of the Ocean Drilling Program Scientific Results, 120, 71-77. Ocean Drilling Program, College Station, TX

Whittaker, J. M., Halpin, J. A., Williams, S. E., Hall, L. S., Gardner, R., Kobler, M. E., Daczko, N. R., Müller, R. D. (2013), Tectonic Evolution and Continental Fragmentation of the Southern West Australian Margin, in S. J. Moss and M. Keep, (Eds.), West Australian Basins Symposium, pp. 1-16, Petroleum Exploration Society of Australia, Perth

Whittaker, J. M., Williams, S. E., Halpin, J. A., Wild, T. J., Stilwell, J. D., Jourdan, F., Daczko, R. (2016), Eastern Indian Ocean microcontinent formation driven by plate motion changes. Earth and Planetary Science Letters, 454, 203-212., doi:10.1016/j.eps1.2016.09.019

Williams, S. E., Whittaker, J. M., Granot, R., Müller, R. D. (2013), Early India-Australia spreading history revealed by newly detected Mesozoic magnetic anomalies in the Perth Abyssal Plain. Journal of Geophysical Research, 118, 3275-3284. doi:10.1002/jgrb.50239

This article is protected by copyright. All rights reserved. 
Williams, S. E., Whittaker, J. M., Müller, R. D. (2011), Full-fit, palinspastic reconstruction of the conjugate Australian $\square$ Antarctic margins. Tectonics, 30, TC6012. doi:10.1029/2011TC002912

Yeates, A. N., Bradshaw, M. T., Dickins, J. M., Brakel, A. T., Exon, N. F., Langford, R. P., Mulholland, S. M., Totterdell, J. M., Yeung, M. (1987), The Westralian superbasin: an Australian link with Tethys, in K. G. McKenzie (Ed.), International symposium on Shallow Tethys 2, Wagga Wagga, N.S.W., pp. 199-213, A. A. Balkema, Rotterdam

Zhou, Q., Liu, Z., Lai, Y., Wang, G.-C., Liao, Z., Li, Y.-X., Wu, J.-Y., Wang, S., Qing, C.-S. (2017), Petrogenesis of mafic and felsic rocks from the Comei large igneous province, South Tibet: Implications for the initial activity of the Kerguelen plume. Geological Society of America Bulletin, 130, 811-824. doi:10.1130/B31653.1

Zhu, D., Mo, X., Pan, G., Zhao, Z., Dong, G., Shi, Y., Liao, Z., Wang, L., Zhou, C. (2008), Petrogenesis of the earliest Early Cretaceous mafic rocks from the Cona area of the eastern Tethyan Himalaya in south Tibet: Interaction between the incubating Kerguelen plume and the eastern Greater India lithosphere? Lithos, 100, 147-175. doi:10.1016/j.lithos.2007.06.024

Zhu, D.-C., Chung, S.-L., Mo, X.-X., Zhao, Z.-D., Niu, Y., Song, B., Yang, Y.-H. (2009), The $132 \mathrm{Ma}$ Comei-Bunbury large igneous province: remnants identified in present-day southeastern Tibet and southwestern Australia. Geology, 37, 583-586. doi:10.1130/G30001A.1

This article is protected by copyright. All rights reserved. 
Table 1

Cretaceous Geomagnetic Time Scales and Ages of Seafloor Spreading Anomalies.

\begin{tabular}{|c|c|c|c|c|c|c|c|c|c|c|c|c|c|}
\hline \multirow[b]{3}{*}{ Age } & \multirow[b]{3}{*}{ Chron } & \multicolumn{8}{|c|}{ Geologic Time Scales } & \multicolumn{4}{|c|}{ Key Spreading Anomalies } \\
\hline & & \multicolumn{2}{|c|}{$\begin{array}{l}\text { Gee \& Kent } \\
(2007)\end{array}$} & \multicolumn{2}{|c|}{$\begin{array}{l}\text { Ogg et al. } \\
\text { (2016) }\end{array}$} & \multicolumn{2}{|c|}{$\begin{array}{l}\text { Malinverno et al. } \\
\text { (2012) }\end{array}$} & \multicolumn{2}{|c|}{ This Study ${ }^{a}$} & \multicolumn{2}{|c|}{$\begin{array}{l}\text { Gibbons et al. } \\
\text { (2013) }\end{array}$} & \multicolumn{2}{|c|}{ This Study ${ }^{\mathrm{a}}$} \\
\hline & & $\begin{array}{l}\text { Begin } \\
\text { (Ma) }\end{array}$ & $\begin{array}{l}\text { End } \\
\text { (Ma) }\end{array}$ & $\begin{array}{l}\text { Begin } \\
\text { (Ma) }\end{array}$ & $\begin{array}{l}\text { End } \\
\text { (Ma) }\end{array}$ & $\begin{array}{l}\text { Begin } \\
\text { (Ma) }\end{array}$ & $\begin{array}{l}\text { End } \\
(\mathrm{Ma})\end{array}$ & $\begin{array}{l}\text { Begin } \\
\text { (Ma) }\end{array}$ & $\begin{array}{l}\text { End } \\
(\mathrm{Ma})\end{array}$ & Chron & $\begin{array}{l}\text { Age } \\
(\mathrm{Ma})\end{array}$ & Chron & $\begin{array}{l}\text { Age } \\
\text { (Ma) }\end{array}$ \\
\hline & C34n & & & 125.93 & 84.19 & 120.95 & & & & C34n & & C34n & $84-121$ \\
\hline Aptian & M0r & 121.00 & 120.60 & 126.30 & 125.93 & 121.54 & 120.95 & 121.8 & - & M0 & 120.4 & M0r & 122 \\
\hline \multirow[t]{4}{*}{ Barremian } & M1n & 123.19 & 121.00 & 128.32 & 126.30 & 123.51 & 121.54 & 123.0 & 121.8 & & & & \\
\hline & M1r & 123.55 & 123.19 & 128.66 & 128.32 & 123.92 & 123.51 & 123.2 & 123.0 & & & & \\
\hline & M2n & 124.05 & 123.55 & - & - & - & - & - & - & & & & \\
\hline & M3n & - & - & 129.11 & 128.66 & 124.58 & 123.92 & 123.7 & 123.2 & M2 & 124.1 & M3n & 124 \\
\hline \multirow[t]{2}{*}{ Barremian } & M3r & 125.67 & 124.05 & 130.60 & 129.11 & 126.05 & 124.58 & 125.8 & 123.7 & & & & \\
\hline & M5n & 126.57 & 125.67 & 131.43 & 130.60 & 127.19 & 126.05 & 126.7 & 125.8 & M4 & 126.7 & M5n & 126 \\
\hline \multirow[t]{12}{*}{ Hauterivian } & M5r & 126.91 & 126.57 & 131.74 & 131.43 & 127.98 & 127.19 & 127.0 & 126.7 & & & & \\
\hline & M6n & 127.11 & 126.91 & 131.92 & 131.74 & 128.15 & 127.98 & 127.1 & 127.0 & M6 & 127.2 & M6n & 127 \\
\hline & M6r & 127.23 & 127.11 & 132.04 & 131.92 & 128.33 & 128.15 & 127.2 & 127.1 & & & & \\
\hline & M7n & 127.49 & 127.23 & 132.27 & 132.04 & 128.54 & 128.33 & 127.4 & 127.2 & & & & \\
\hline & $\mathrm{M} 7 \mathrm{r}$ & 127.79 & 127.49 & 132.55 & 132.27 & 129.00 & 128.54 & 127.7 & 127.4 & & & & \\
\hline & M8n & 128.07 & 127.79 & 132.80 & 132.55 & 129.32 & 129.00 & 128.1 & 127.7 & M8 & 128.2 & M8n & 128 \\
\hline & M8r & 128.34 & 128.07 & 133.05 & 132.80 & 129.67 & 129.32 & 128.4 & 128.1 & & & & \\
\hline & M9n & 128.62 & 128.34 & 133.30 & 133.05 & 130.02 & 129.67 & 128.8 & 128.4 & & & & \\
\hline & M9r & 128.93 & 128.62 & 133.58 & 133.30 & 130.43 & 130.02 & 129.3 & 128.8 & & & & \\
\hline & M10n & 129.25 & 128.93 & 133.88 & 133.58 & 130.76 & 130.43 & 130.0 & 129.3 & M10 & 130.5 & M10n & 130 \\
\hline & M10r & 129.63 & 129.25 & 134.22 & 133.88 & 131.07 & 130.76 & 130.5 & 130.0 & & & & \\
\hline & M10Nn.1n & n $\quad 129.91$ & 129.63 & 134.48 & 134.22 & 131.35 & 131.07 & 130.9 & 130.5 & M10N & 131 & M10N & 131 \\
\hline \multirow{2}{*}{$\begin{array}{l}\text { Hauterivian } \\
--------------\end{array}$} & M10Nn.1r & $\mathrm{r} \quad 129.95$ & 129.91 & 134.51 & 134.48 & 131.47 & 132.35 & 131.0 & 130.9 & & & & \\
\hline & M10Nn.2n & 130.22 & 129.95 & 134.76 & 134.51 & 131.71 & 131.47 & 131.3 & 131.0 & & & & \\
\hline \multirow[t]{5}{*}{ Valanginian } & M10Nn.2r & r $\quad 130.24$ & 130.22 & 134.78 & 134.76 & 131.83 & 131.71 & 131.4 & 131.3 & & & & \\
\hline & M10Nn.3n & n $\quad 130.49$ & 130.24 & 135.00 & 134.78 & 132.01 & 131.83 & 131.6 & 131.4 & & & & \\
\hline & $\mathrm{M} 10 \mathrm{Nr}$ & 130.84 & 130.49 & 135.32 & 135.00 & 132.30 & 132.01 & 131.9 & 131.6 & & & & \\
\hline & M11n & 131.50 & 130.84 & 135.92 & 135.32 & 132.67 & 132.30 & 132.5 & 131.9 & M11 & 132.1 & M11n & 132 \\
\hline & M11r & 131.91 & 131.50 & 136.29 & 135.92 & 132.99 & 132.67 & 132.9 & 132.5 & & & M11r & 133 \\
\hline
\end{tabular}

${ }^{\mathrm{a}}$ Chron ages from geomagnetic time scale of Ogg et al. (2102) adjusted to fit stage and ammonite zone boundary ages of Aguirre-Urreta et al. (2019) complemented with cyclostratigraphy of Bodin et al. (2006) from M1n to M0r and of Martinez et al. (2013) from M10Nn.2n to M11r as shown in Table 2. The base of chron M0r is assigned to the middle of the last ammonite zone of the Barremian stage as indicated by chemo- and biostratigraphic data of Frau et al. (2018), giving an age that corresponds to the youngest age assessed by Olierook et al. (2019). 


\section{Table 2}

Revised Hauterivian and lower Barremian Chron Ages.

\begin{tabular}{|c|c|c|c|c|c|c|c|c|}
\hline Chron & $\begin{array}{l}\text { Position in Ammonite } \\
\text { Zone (Ogg et al., 2016) }\end{array}$ & $\begin{array}{l}\text { Age at Base } \\
\text { of } \\
\text { Ammonite } \\
\text { Zone (Ma) }\end{array}$ & $\begin{array}{l}\text { Age at Top } \\
\text { of } \\
\text { Ammonite } \\
\text { Zone (Ma) }\end{array}$ & $\begin{array}{l}\text { Revised Age } \\
\text { at Base of } \\
\text { Chron }(\mathrm{Ma})^{\mathrm{a}}\end{array}$ & $\begin{array}{l}\text { Gee and Kent } \\
(2007) \text { Age } \\
\text { at Base of } \\
\text { Chron }(\mathrm{Ma})\end{array}$ & $\begin{array}{l}\text { Age } \\
\text { Difference } \\
\text { (m.y.) }\end{array}$ & $\begin{array}{l}\text { Malinverno } \\
\text { et al. (2012) } \\
\text { Age at Base } \\
\text { of Chron } \\
\text { (Ma) }\end{array}$ & $\begin{array}{l}\text { Age } \\
\text { Difference } \\
\text { (m.y.) }\end{array}$ \\
\hline MOr & $\begin{array}{l}50 \% \text { within Sarasini }{ }^{\mathrm{b}} \\
27 \% \text { within }\end{array}$ & 122.019 & 121.519 & 121.8 & 121.00 & 0.8 & 121.54 & 0.3 \\
\hline M1n & Sartousiana & 123.199 & 122.339 & 123.0 & 123.19 & 0.2 & 123.51 & 0.5 \\
\hline M1r & $\begin{array}{l}96 \% \text { within } \\
\text { Vandenheckii }\end{array}$ & 123.999 & 123.199 & 123.2 & 123.55 & 0.3 & 123.92 & 0.7 \\
\hline M3n & $\begin{array}{l}38 \% \text { within } \\
\text { Vandenheckii }\end{array}$ & 123.999 & 123.199 & 123.7 & 124.05 & 0.3 & 124.58 & 0.9 \\
\hline $\mathrm{M} 3 \mathrm{r}$ & $43 \%$ within Hugii & 126.079 & 125.539 & 125.8 & 125.67 & 0.1 & 126.05 & 0.3 \\
\hline M5n & $18 \%$ within Ohmi & 126.835 & 126.079 & 126.7 & 126.57 & 0.1 & 127.19 & 0.5 \\
\hline M5r & $79 \%$ within Balearis & 127.497 & 126.835 & 127.0 & 126.91 & 0.1 & 127.98 & 1.0 \\
\hline M6n & $57 \%$ within Balearis & 127.497 & 126.835 & 127.1 & 127.11 & 0.0 & 128.15 & 1.1 \\
\hline M6r & $42 \%$ within Balearis & 127.497 & 126.835 & 127.2 & 127.23 & 0.0 & 128.33 & 1.1 \\
\hline M7n & $13 \%$ within Balearis & 127.497 & 126.835 & 127.4 & 127.49 & 0.1 & 128.54 & 1.1 \\
\hline $\mathrm{M} 7 \mathrm{r}$ & $63 \%$ within Ligatus & 128.145 & 127.497 & 127.7 & 127.79 & 0.1 & 129.00 & 1.3 \\
\hline M8n & $11 \%$ within Ligatus & 128.145 & 127.497 & 128.1 & 128.07 & 0.0 & 129.32 & 1.2 \\
\hline M8r & $69 \%$ within Sayni & 129.099 & 128.145 & 128.4 & 128.34 & 0.1 & 129.67 & 1.3 \\
\hline M9n & $30 \%$ within Sayni & 129.099 & 128.145 & 128.8 & 128.62 & 0.2 & 130.02 & 1.2 \\
\hline M9r & $\begin{array}{l}74 \% \text { within } \\
\text { Nodosoplicatum }\end{array}$ & 129.992 & 129.099 & 129.3 & 128.93 & 0.4 & 130.43 & 1.1 \\
\hline M10n & $97 \%$ within Loryi & 130.520 & 129.992 & 130.0 & 129.25 & 0.8 & 130.76 & 0.8 \\
\hline M10r & $9 \%$ within Loryi & 130.520 & 129.992 & 130.5 & 129.63 & 0.9 & 131.07 & 0.6 \\
\hline M10Nn.1n & $49 \%$ within Radiatus & 131.292 & 130.520 & 130.9 & 129.91 & 1.0 & 131.35 & 0.4 \\
\hline M10Nn.1r & $40 \%$ within Radiatus & 131.292 & 130.520 & 131.0 & 129.95 & 1.1 & 131.47 & 0.5 \\
\hline M10Nn.2n & $89 \%$ within Furcillata & 131.935 & 131.292 & 131.4 & 130.22 & 1.2 & 131.71 & 0.3 \\
\hline M10Nn.2r & $86 \%$ within Furcillata & 131.935 & 131.292 & 131.4 & 130.24 & 1.2 & 131.83 & 0.4 \\
\hline M10Nn.3n & $51 \%$ within Furcillata & 131.935 & 131.292 & 131.6 & 130.49 & 1.1 & 132.01 & 0.4 \\
\hline $\mathrm{M} 10 \mathrm{Nr}$ & Base Furcillata & 131.935 & 131.292 & 131.9 & 130.84 & 1.1 & 132.30 & 0.4 \\
\hline M11n & $59 \%$ within Peregrinus & 133.393 & 131.935 & 132.5 & 131.50 & 1.0 & 132.67 & 0.2 \\
\hline
\end{tabular}


using revised stage ages of Aguirre-Urreta et al. (2019) complemented with cyclostratigraphy of Bodin et al. (2006) from M1n to M3n and cyclostratigraphy of Martinez et al. (2013) from M10Nn.2n to M11r. Geomagentic time scales of Gee and Kent (2007) and Malinverno et al. (2012) shown for comparison.

${ }^{\mathrm{b}}$ The biostratigraphic position of chron M0r was revised in Frau et al. (2018). The age given here assumes the base of this chron is in the middle of the Sarasini Zone. 


\section{Table 3}

Petrogenetic Modeling Input Parameters and Results.

\begin{tabular}{|c|c|c|c|}
\hline \multirow{2}{*}{$\begin{array}{l}\text { Major Elements } \\
\mathrm{SiO}_{2}\end{array}$} & $\begin{array}{l}\text { Sample 67R-01W Measured } \\
\text { Composition (wt } \%)^{\mathrm{a}}\end{array}$ & $\begin{array}{l}\text { Modeled Magma } \\
\text { Chamber } \\
\text { Composition (wt \%) }\end{array}$ & $\begin{array}{l}\text { Modeled Primary } \\
\text { Basalt Magma } \\
\text { Composition (wt \%) }\end{array}$ \\
\hline & 49.11 & 49.09 & 48.54 \\
\hline $\mathrm{TiO}_{2}$ & 0.54 & 0.53 & 0.50 \\
\hline $\mathrm{Al}_{2} \mathrm{O}_{3}$ & 18.99 & 18.97 & 17.63 \\
\hline $\mathrm{FeO}$ & 7.76 & 7.78 & 7.79 \\
\hline $\mathrm{MnO}$ & 0.16 & 0.15 & 0.15 \\
\hline $\mathrm{MgO}$ & 11.66 & 11.67 & 14.44 \\
\hline $\mathrm{CaO}$ & 9.41 & 9.40 & 8.73 \\
\hline $\mathrm{Na}_{2} \mathrm{O}$ & 2.31 & 2.32 & 2.15 \\
\hline $\mathrm{K}_{2} \mathrm{O}$ & 0.03 & 0.03 & 0.03 \\
\hline $\mathrm{P}_{2} \mathrm{O}_{5}$ & 0.04 & 0.05 & 0.04 \\
\hline$S U M$ & 100.00 & 100.00 & 100.00 \\
\hline \multicolumn{2}{|c|}{ Other key compositional indicators } & $\begin{array}{l}\text { Modeled Magma } \\
\text { Chamber }\end{array}$ & $\begin{array}{l}\text { Modeled Primary } \\
\text { Basalt }\end{array}$ \\
\hline \multicolumn{2}{|c|}{$\mathrm{Ni}$ content of olivine (wt\%) } & 0.35 & 0.49 \\
\hline \multicolumn{2}{|c|}{ Forsterite content of olivine (wt \%) } & 91.0 & 91.9 \\
\hline \multicolumn{2}{|l|}{ Mg\# of basalt } & 0.73 & 0.77 \\
\hline \multicolumn{2}{|c|}{$\mathrm{FeO} / \mathrm{Fe}_{2} \mathrm{O}_{3}$ (total) ratio } & 0.87 & 0.89 \\
\hline \multicolumn{2}{|c|}{ Water content (wt\%) } & 0.00 & 0.01 \\
\hline & $\begin{array}{l}\text { Modeled Magma } \\
\text { Chamber }\end{array}$ & $\begin{array}{l}\text { Modeled Primary } \\
\text { Basalt }\end{array}$ \\
\hline \multicolumn{2}{|c|}{$\begin{array}{l}\text { Modeled melting conditions } \\
\text { Magma temperature using method of Ariskin (1999) } \\
\left({ }^{\circ} \mathrm{C}\right)\end{array}$} & 1296 & 1369 \\
\hline \multicolumn{2}{|c|}{$\begin{array}{l}\text { Magma temperature using method of Kimura and } \\
\text { Ariskin }(2014)\left({ }^{\circ} \mathrm{C}\right)\end{array}$} & - & 1413 \\
\hline \multicolumn{2}{|c|}{$\begin{array}{l}\text { Magma temperature using method of Herzberg and } \\
\text { Asimow }(2008)\left({ }^{\circ} \mathrm{C}\right)\end{array}$} & - & 1413 \\
\hline \multicolumn{2}{|c|}{ Modeled mantle potential temperature $\left({ }^{\circ} \mathrm{C}\right)$} & & $1380-1410$ \\
\hline \multicolumn{2}{|c|}{ Melting pressure (GPa) } & 0.00 & 1.5 \\
\hline \multicolumn{2}{|l|}{ Degree of melting } & - & 24.8 \\
\hline \multicolumn{2}{|c|}{ Degree of fractionation } & - & 10 \\
\hline
\end{tabular}

${ }^{a}$ Based on X-Ray Fluorescence analysis using AXIOS Plus (Panalytical) instrument at University of Oldenburg on shipboard residual sample powder previously analyzed by ICP-AES (Huber et al., 2019a).

This article is protected by copyright. All rights reserved. 


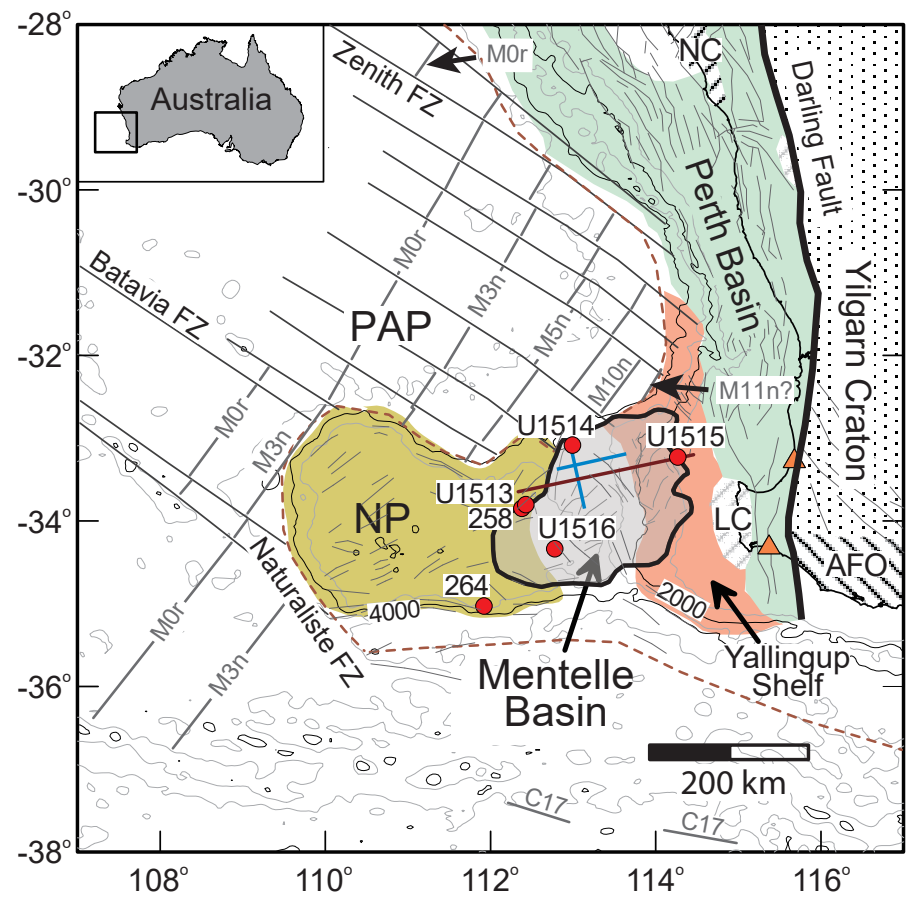

This article is protected by copyright. All rights reserved. 

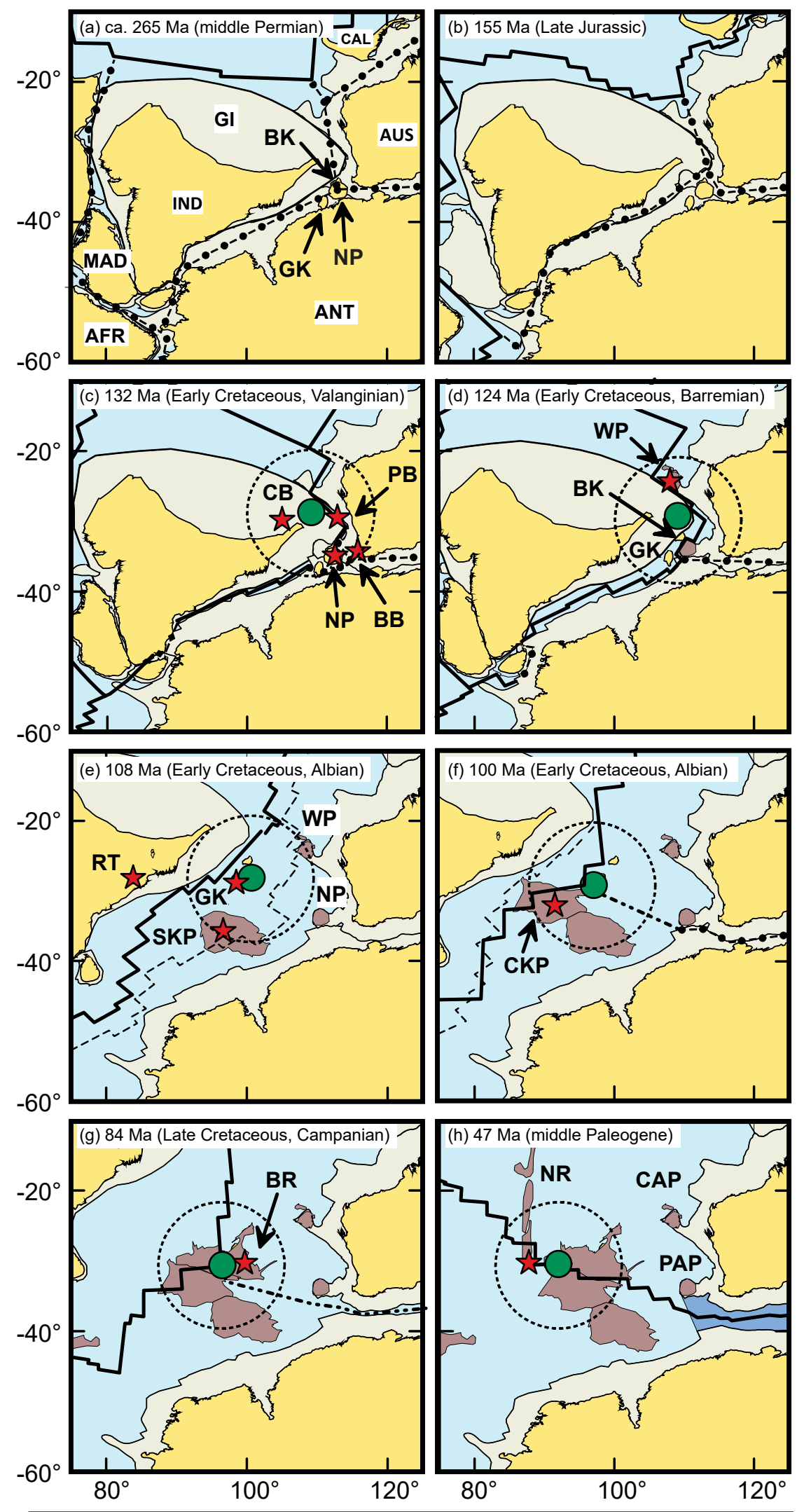

This article

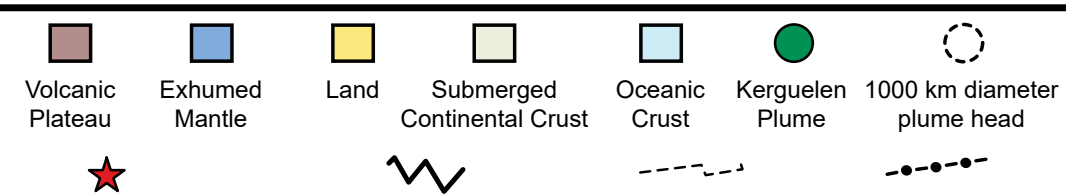

Volcanic Center Spreading Ridge Rift

Continental Crust: AFR - Africa, ANT - Antarctica, AUS - Australia, BK - Batavia Knoll, CAL - Central Argoland,GI - Greater India, GK - Gulden Draak Knoll IND - India, MAD - Madagascar, NP - Naturaliste Plateau Seafloor: CAP - Cuvier Abyssal Plain, PAP - Perth Abyssal Plain

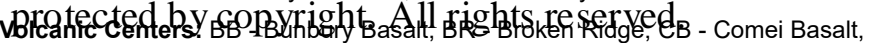



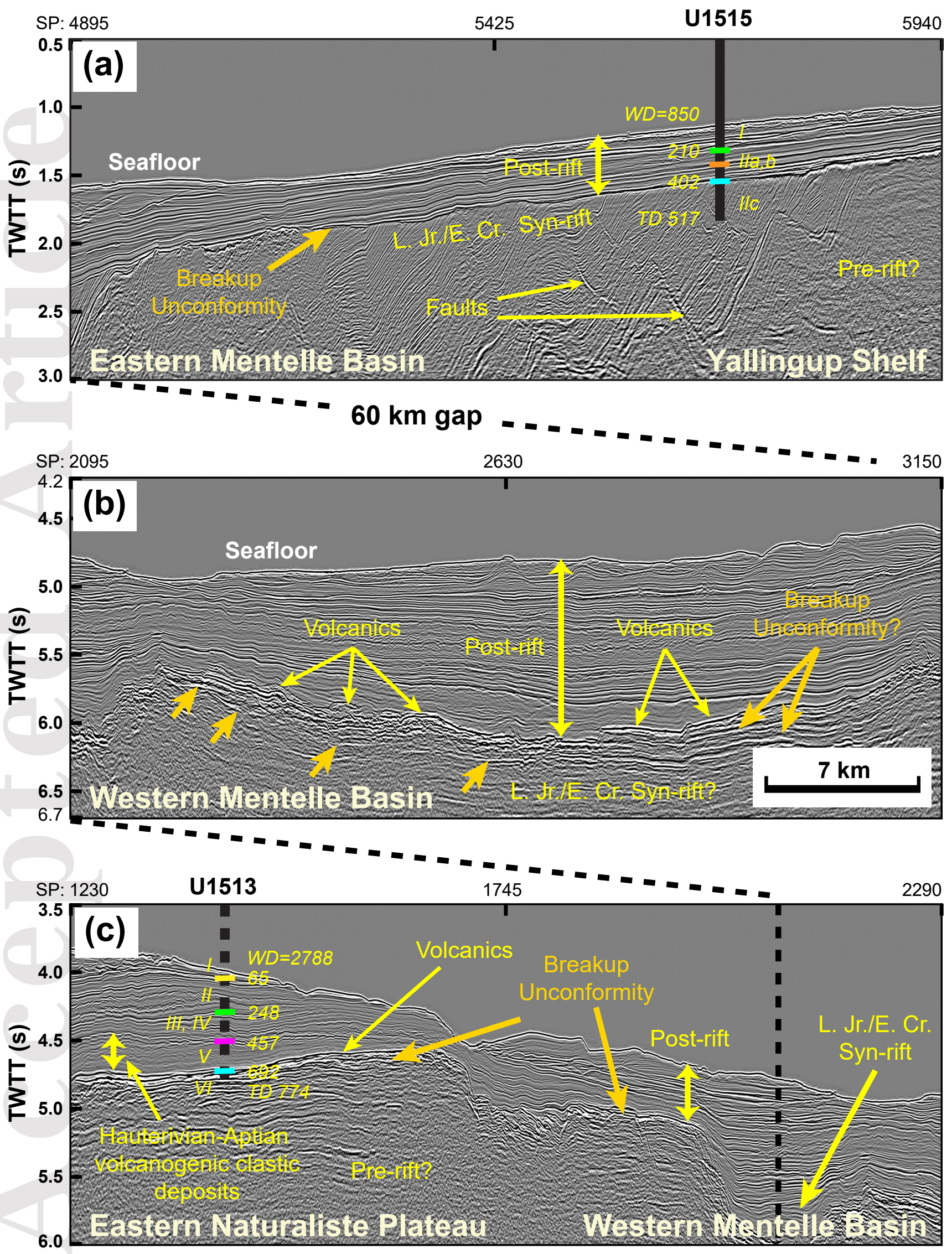

This article is protected by copyright. All rights reserved. 


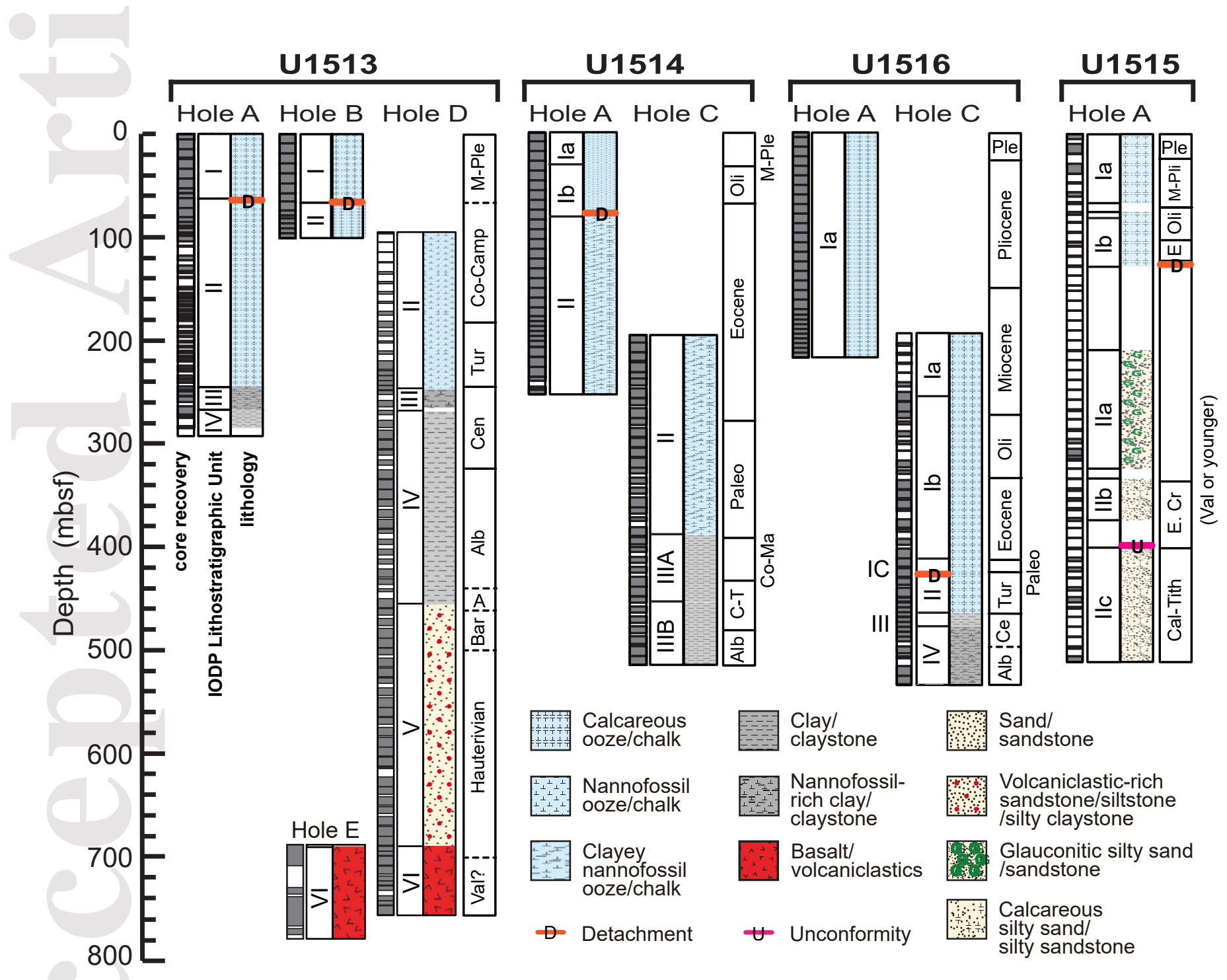

This article is protected by copyright. All rights reserved. 


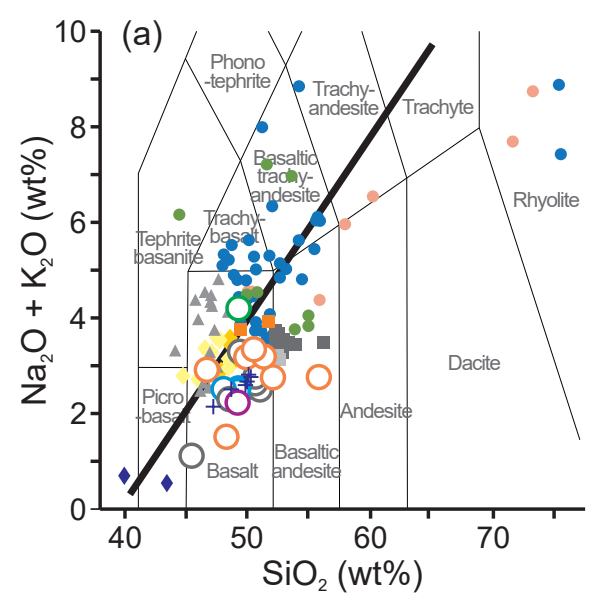

Naturaliste Plateau
Site U1513
O Unit 3
O Unit 5
O Unit 7
O Unit 9
O dike
volcaniclastic unit
- DSDP 264
- dredges, south
dredges, north
Bunbury Basalt
Casuarina
- Gosselin
Olierook et al.
(2016)
Kerguelen Plateau
ODP 1140, glass
ODP 1140, basalt
- plume
+ SEIR
- LOI <5\%
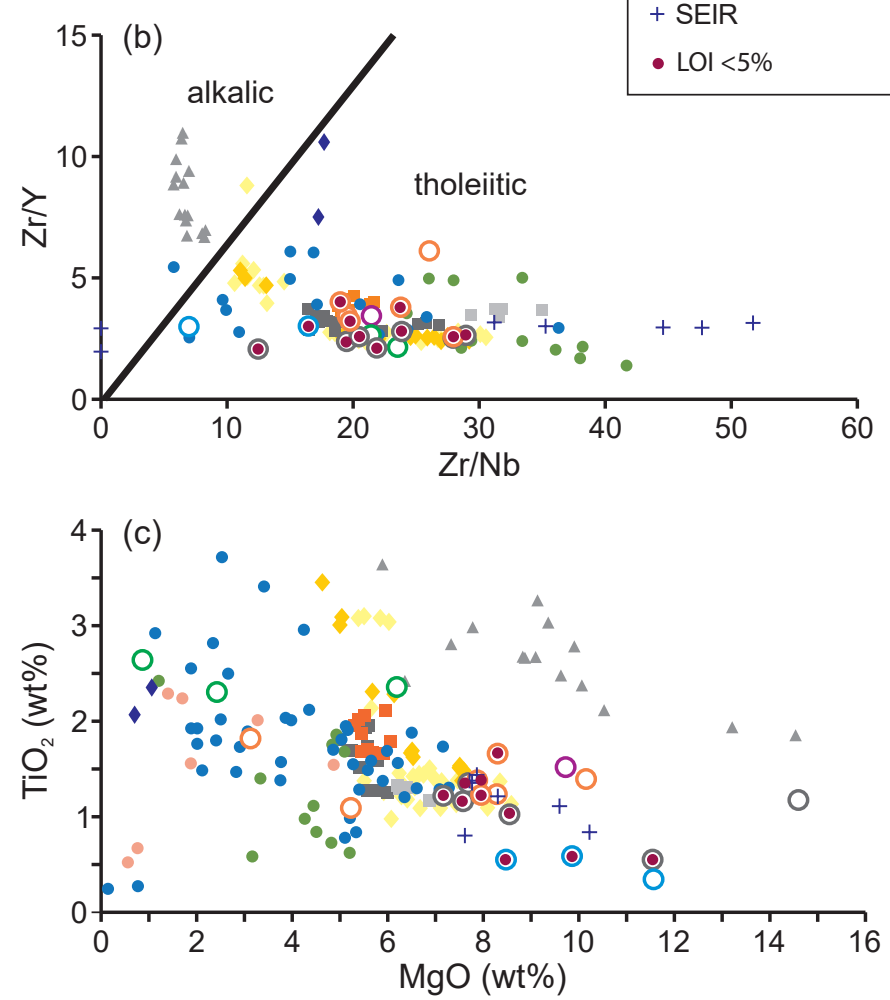

This article is protected by copyright. All rights reserved. 

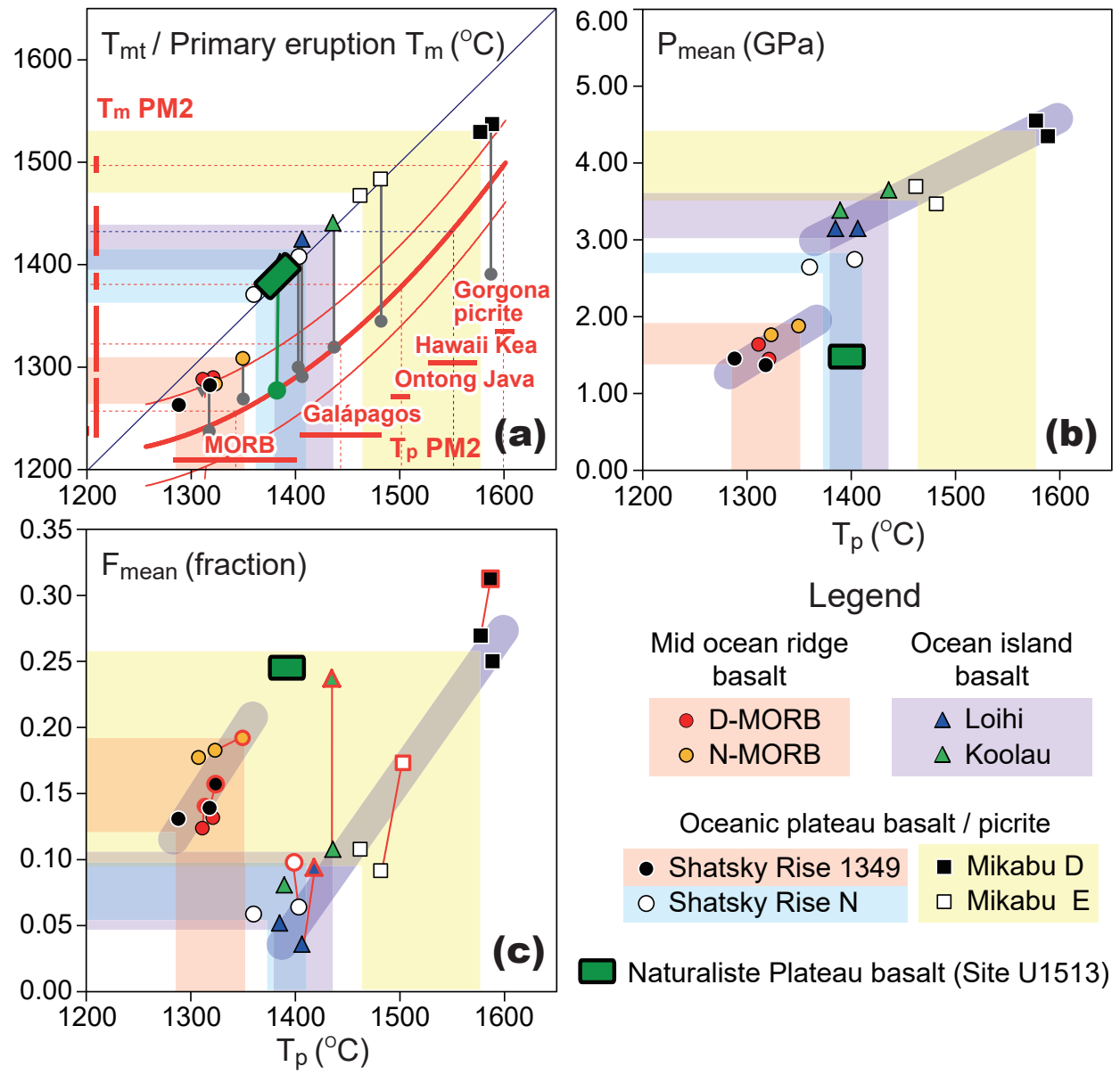

Legend Mid ocean ridge Ocean island basalt basalt

- D-MORB $\quad \Delta$ Loihi

O N-MORB

$\triangle$ Koolau

Oceanic plateau basalt / picrite

- Shatsky Rise 1349 - Mikabu D

o Shatsky Rise N $\square$ Mikabu E

(c)

(Site U1513)

This article is protected by copyright. All rights reserved. 


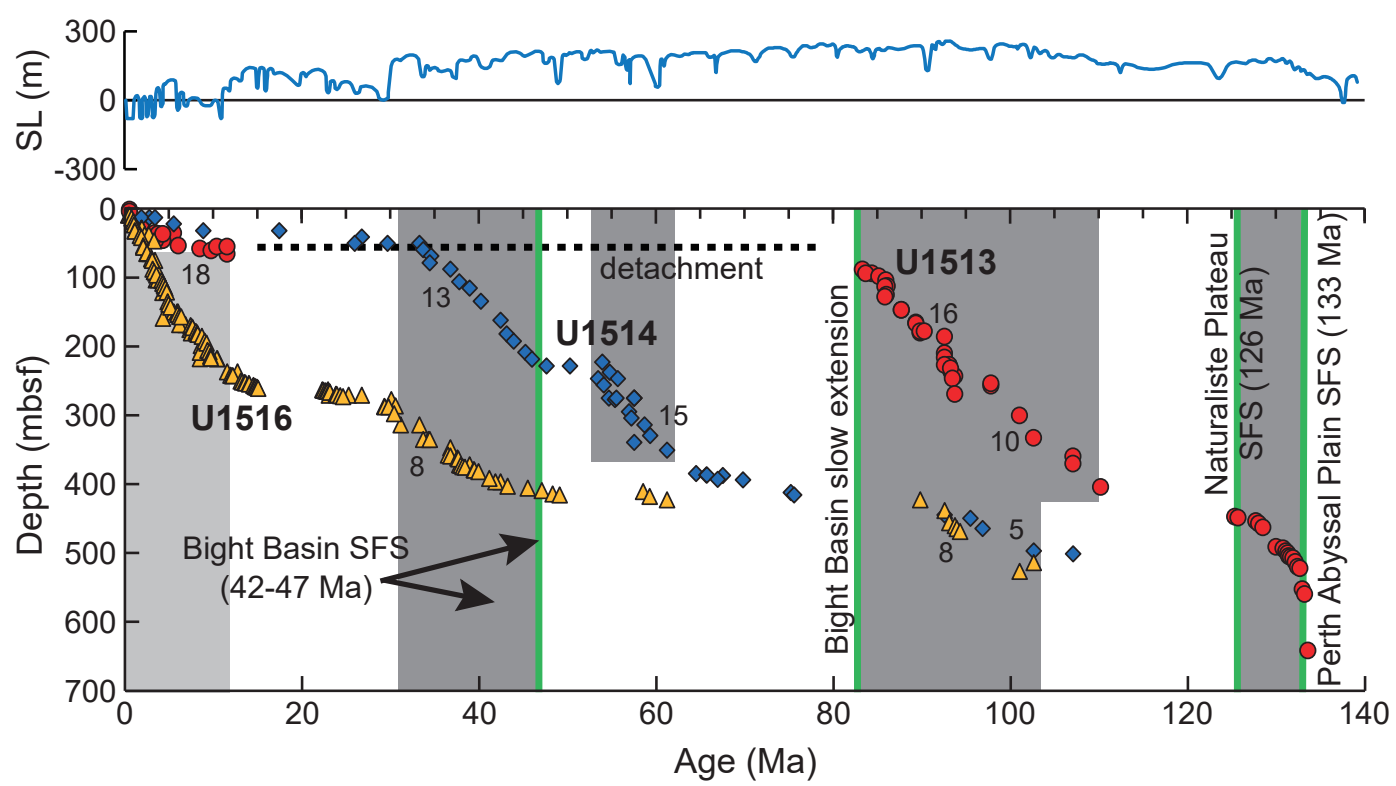

This article is protected by copyright. All rights reserved. 
(a) middle Jurassic (Pre-rift)

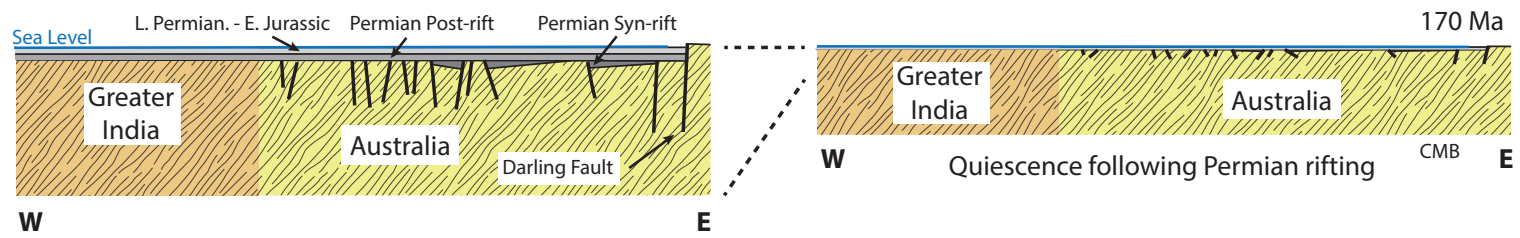

(b) Late Jurassic (rifting and uplift)

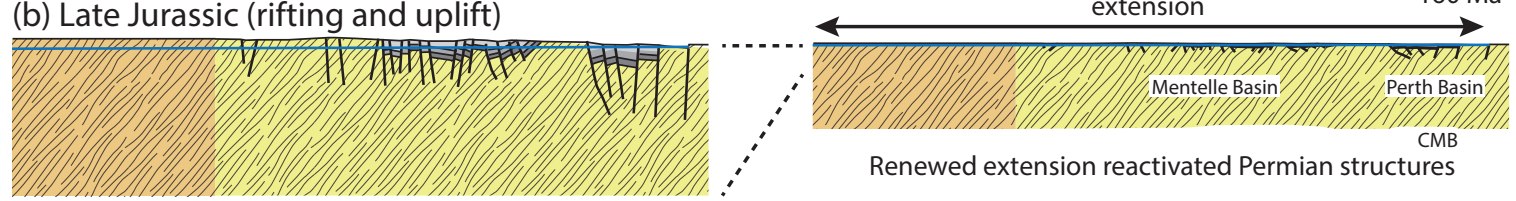

(c) middle Valanginian (Perth Abyssal Plain breakup)

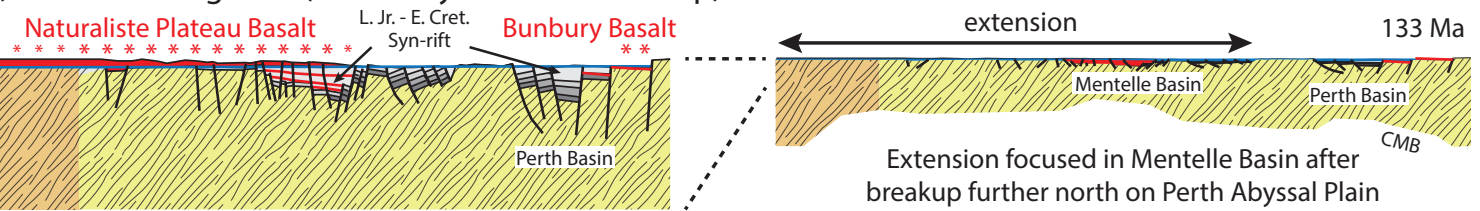

(d) late Hauterivian (Naturaliste Plateau breakup)

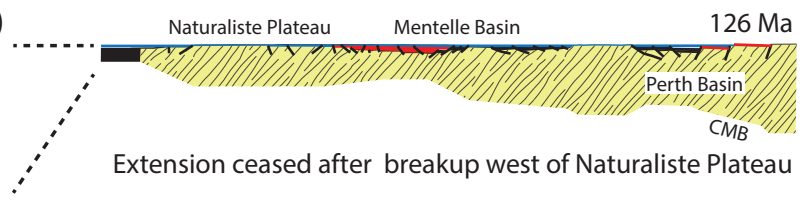

(e) Late Cretaceous (Southern margin rifting)
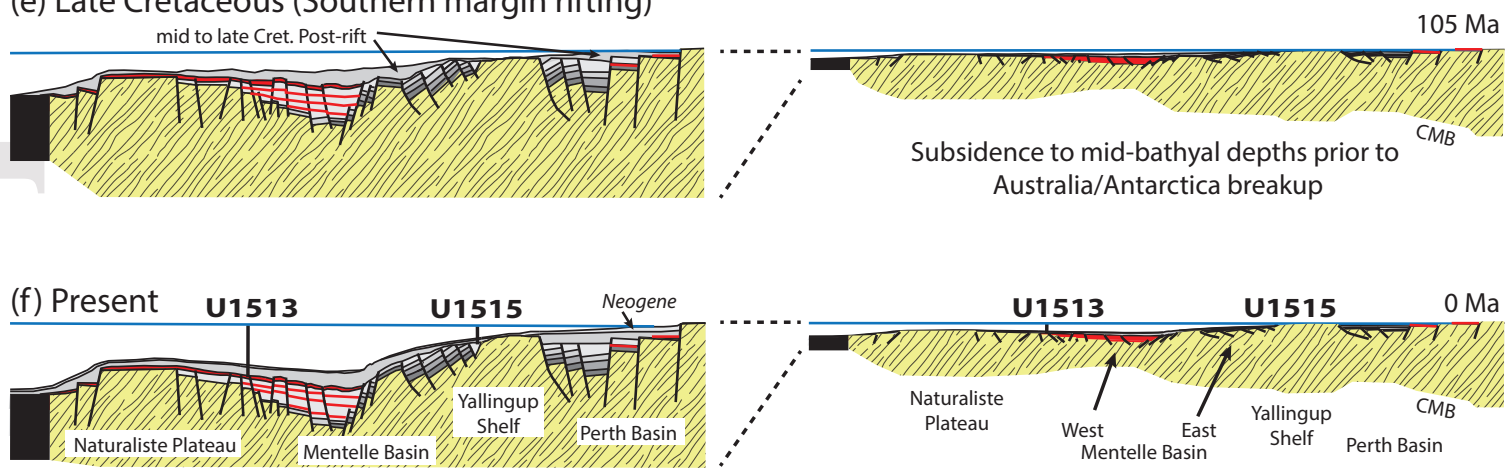

V.E. $=5: 1$

$100 \mathrm{~km}$

V.E. $=1: 1$

This article is protected by copyright. All rights reserved. 


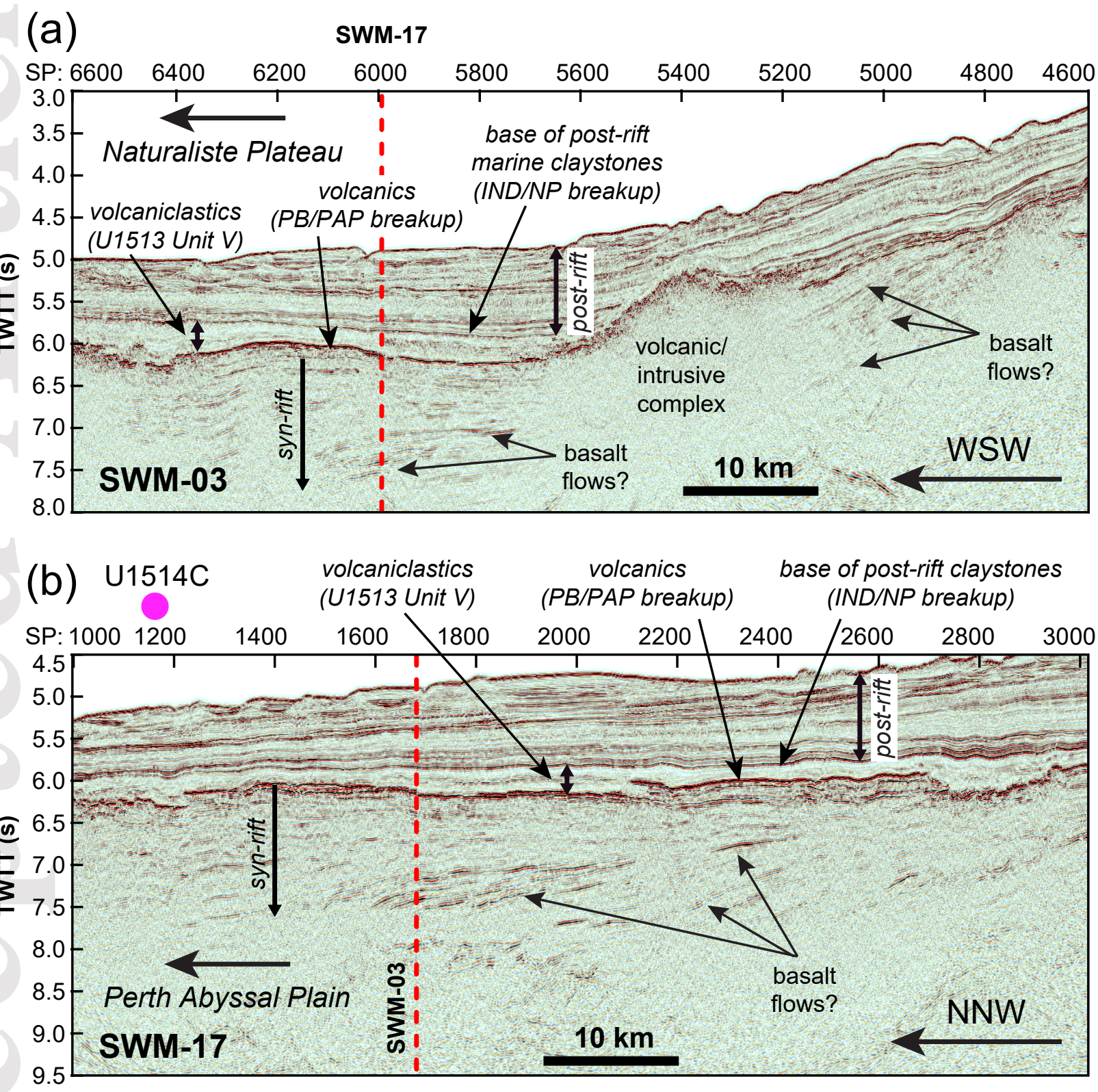

This article is protected by copyright. All rights reserved. 